\title{
Current research and prevention of aflatoxins in China
}

\author{
E. Tumukunde, G. Ma, D. Li, J. Yuan, L. Qin and S. Wang" \\ Key Laboratory of Pathogenic Fungi and Mycotoxins of Fujian Province and School of Life Sciences, Fujian Agriculture and \\ Forestry University, Fuzhou 350002, China P.R.; wshmail@m.fafu.edu.cn
}

Received: 22 July 2019 / Accepted: 7 November 2019

( 2020 Wageningen Academic Publishers

OPEN ACCESS CP) REVIEW ARTICLE

\begin{abstract}
Since their discovery in the 1960s, aflatoxins were found to have a considerable impact on the health of humans and animals as well as the country's economy and international trade. Aflatoxins are often found in nuts, cereals and animal feeds, which has a significant danger to the food industry. Over the years, several steps have been undertaken worldwide to minimise their contamination in crops and their exposure to humans and animals. China is one of the largest exporters and importers of food and animal feed. As a result, many studies have been carried out in China related to aflatoxins, including their distribution, pollution, detection methods, monitoring, testing and managing. Chinese scientists studied aflatoxins in microbiological, toxicological, ecological effects as well as policies relating to their controlling. China has thus put into practice a number of strategies aiming at the prevention and control of aflatoxins in order to protect consumers and ensure a safe trade of food and feed, and the status and enlargement of these strategies are very important and useful for many consumers and stakeholders in China. Therefore, this article aims at the detriment assessments, regulations, distribution, detection methods, prevention and control of aflatoxins in China. It equally provides useful information about the recent safety management systems in place to fight the contamination of aflatoxins in food and feed in China.
\end{abstract}

Keywords: aflatoxins, Aspergillus species, region, distribution, prevention and control

\section{Introduction}

Aflatoxins are among the major mycotoxins (Sun et al., 2017) and they are widely known as a group of cancercausing chemicals and highly toxic secondary metabolites produced by members of fungal Aspergillus genus (Wild and Turner, 2002; Williams et al., 2004), such as Aspergillus parasiticus, Aspergillus flavus and Aspergillus nominus (AlGabr et al., 2013; Rawal et al., 2010). A research conducted by Ma et al. (2014) reported that food safety issues caused by mycotoxins have caught a large attention worldwide and aflatoxins are known as the main representative toxins. It was also indicated that these aflatoxins can cause serious health issues to both humans and animals. However, the toxic properties of aflatoxins manifest themselves in a diverse way based on the dose, test system and duration of exposure (Dhanasekaran et al., 2011; Khlangwiset et al., 2011). Recent studies indicate that the aflatoxin-producing fungus A. flavus is one of the main causes of invasive and non-invasive aspergillosis (Amaike and Keller, 2011;
Gonçalves et al., 2012; Hedayati et al., 2007; Yu et al., 2005) and aflatoxicosis (Cardwell and Henry, 2004; Farombi, 2006). The former is an infection caused by inhalation of spores of the aflatoxin-producing fungus $A$. flavus through the respiratory tract, while the latter is caused by the ingestion of aflatoxins (Fouad et al., 2019; Liu et al., 2016). Aflatoxin contamination can occur either in the field or during storage or during transit of crops (Santos Pereira et al., 2019; Zhang et al., 2015). However, the pathogenicity of aflatoxin-producing fungi in agricultural commodities increases with the presence of insects and stress on the host (Agrios, 2005; Diao et al., 2015). It has also been reported that high temperatures and extreme moisture conditions of storage for legumes and grains increase the amount of aflatoxins produced by the fungal species (Amaike and Keller, 2011; Li et al., 2014).

Another study reported the aflatoxins as a highly contaminating toxin in food crops, such as groundnuts and their products, dried fruit, tree nuts, spices, rice, cottonseed, 
wheat and maize under particular temperature and moisture conditions (Barrett, 2005; Li et al., 2009a). When these foods are contaminated, it may result in a significant economic loss. Annual destruction of contaminated food crops was anticipated to be $25 \%$ worldwide (WHO, 2018). However, these mycotoxins are especially dominant in some parts of the world, such as Sub-Saharan Africa and Southeast Asia where large amounts of the aforementioned food crops are consumed. In these areas, there is also a high humidity which favours proliferation of aflatoxins-producing fungi (Khlangwiset et al., 2011; Liu and Wu, 2010; McGlynn and London, 2005). In recent years, aflatoxin contamination has become quite a daunting problem for the agricultural industry in China. As a result, many cases of exposure to aflatoxins with a higher incidence of human liver cancer has been reported in different parts of the country (Liao et al., 2009; Wang and Liu, 2007b). In China, various universities and institutions have conducted studies on aflatoxins. Thus, this research reviews the current progress on aflatoxin prevention and management addressing the safety of both living organisms and food in China.

\section{Geographical location and climate of China}

To address the present situation of aflatoxin contamination and prevention in China, the geography, economy, and population of China must be understood (Al-Tamimi, 2017; CIA, 2019; Liu and Diamond, 2005; Stadler, 2015). China is located between the $18^{\circ}$ and $54^{\circ} \mathrm{N}$ latitudes of the equator (Goss et al., 2014). Given the vast and complex topography of the country, both the environmental and climate conditions differ from one region to the other (Lin et al., 2015; Zheng et al., 2010). Therefore, the dissimilarity of climate in the regions provides different favourable environments for aflatoxin production and the growth of aflatoxin-producing fungi. In the $21^{\text {st }}$ century, aflatoxin contamination is mostly observed in peanuts, maize and cereals in nearly every province of China (Woo and ElNezami, 2014). In general, serious problems caused by aflatoxins are observed in the southern region of China, due to heavy rain and warm temperatures that allow the growth of aflatoxin-producing fungi (Li et al., 2001; Wu et al., 2016b). A high rate of liver cancer, which is caused by aflatoxin exposure, was particularly reported in Guangxi province (Li et al., 2001; Woo and El-Nezami, 2014). However, due to the increase of aflatoxin contamination in food crops or feedstuffs and the escalating health risk of exposure to these toxins, several strategies to investigate and monitor aflatoxins have been initiated in China. These were implemented to protect consumers from exposure and to ensure food safety (Zhang et al., 2013). In the light of the above information, it is clear that the optimal conditions for aflatoxins production differ from one location to another, owing to China's huge landscape with different climate zones.

\section{Aflatoxin regulation in China}

The International Agency for Research on Cancer (IARC) recently highlighted aflatoxins carcinogenicity and classified them as group 1 carcinogenic - being able to influence the DNA structure of exposed organisms (Hell et al., 2008). Aflatoxins were initially identified in the 1960s in the UK after more than 100,000 turkey poults died of toxins from mould-contaminated peanut meal (Monson et al., 2014; Wannop, 1961; Wogan and Goldblatt, 1969). The toxin was then named 'aflatoxin' after its fungal producer $A$. flavus (Negash, 2018). To date, about 18 types of aflatoxins have been discovered, but only $4-$ aflatoxin $B_{1}, B_{2}, G_{1}$ and $G_{2}$ $\left(\mathrm{AFB}_{1}, \mathrm{AFB}_{2}, \mathrm{AFG}_{1}\right.$, and $\mathrm{AFG}_{2}$ ) - are studied extensively and are well-known for their toxicological effects (Bakırdere et al., 2012; Mzungu et al., 2018; Xie et al., 2016). The letters $B$ and $G$ refer to their fluorescence colour under ultraviolet light (B for Blue, $G$ for Green) and the numbers represent their relative migration distance on a thin layer chromatographic plate (Kew, 2013; Liu et al., 2013; Ventura et al., 2004). These toxins are highly toxic and are usually found in all the main food crops such as grains, nuts, and their derived products. Thus, once humans or animals are more exposed to contaminated foods, it may lead to severe health issues (WHO, 2018). $\mathrm{AFM}_{1}$ and $\mathrm{AFM}_{2}$ are other known aflatoxins which are the metabolites of $\mathrm{AFB}_{1}$ and $\mathrm{AFB}_{2}$ respectively, and they are found in the milk of animal exposed to contaminated food. Consequently, humans can also be exposed to these aflatoxins through intake of milk and their derived products initially collected from the infected animal (Bianco et al., 2012; Goldblatt, 2012). Among all these toxins aflatoxin $B_{1}$ is the most abundant toxin and the most intoxicating substance (Li et al., 2018).

Due to potent carcinogenic and toxic properties of aflatoxins, many of the developed countries established very strict regulations that limit the highest allowable aflatoxin concentration in feed and food. Some of the developing countries, such as Mexico and China, have also set up rules consistent with those in the United States for both trading and human consumption (Table 1). In Asia and the Pacific, China has been reported as the country with the most detailed and extensive regulations for mycotoxins (Zhao et al., 2013). The limits in $\mathrm{AFB}_{1}$ contents in some foodstuff in China are outlined in Table 1. Typical examples include but are not limited to maize, peanuts and their derived products $(\leq 20 \mu \mathrm{g} / \mathrm{kg})$, edible vegetable oil, rice, and irradiated rice $(\leq 10 \mu \mathrm{g} / \mathrm{kg})$ as well as vinegar, beans, fermented foods, starch products, fermented wine, pastry biscuit $(\leq 5 \mu \mathrm{g} / \mathrm{kg})$. Furthermore, the limit of $\mathrm{AFM}_{1}$ in dairy products and milk is $\leq 5 \mu \mathrm{g} / \mathrm{kg}$. These regulations were set in order to protect the consumer against the detrimental effects of aflatoxins (Liu et al., 2006b). In 2003, more than 99 countries had established regulations relating to mycotoxins in food and feed. Most of these countries have at least set up regulatory limits for $\mathrm{AFB}_{1}$ content, while some of them 
have established limits for the total of the 4 main aflatoxins $\left(\mathrm{AFT}=\mathrm{AFB}_{1}+\mathrm{AFB}_{2}+\mathrm{AFG}_{1}+\mathrm{AFG}_{2}\right)($ Guzmán-de-Peña and Peña-Cabriales, 2005). Hence, the current worldwide allowed levels of both $\mathrm{AFB}_{1}$ and $\mathrm{AFT}$ are in the range of $1 \sim 20 \mu \mathrm{g} / \mathrm{kg}$ and $0 \sim 35 \mu \mathrm{g} / \mathrm{kg}$, respectively, consistent with the aforementioned Chinese regulations (Ding et al., 2012; Van Egmond and Jonker, 2004).

In summary, it is believed that by imposing certain regulations aiming at the limitation of the total amount of aflatoxins allowed in feed and foodstuffs in China, the efforts could significantly reduce potential exposure to aflatoxins and improve the safety of consumers in the country.

\section{The main fungal species producing aflatoxins in China}

A. flavus, A. parasiticus and A. nomius are the known fungal species that are able to produce aflatoxins. However, it was also discovered that about 20 different types of aspergilli, such as Aspergillus nidulans, and some other species of Bipolaris, Chaetomium, Monocillium, and Farrowia can also produce sterigmatocystin (ST) which was subsequently identified as a highly toxic intermediate in the $\mathrm{AFB}_{1}$ biosynthetic pathway (Heidtmann-Bemvenuti et al., 2011; Zheng et al., 2012). It was also uncovered that the aflatoxin cluster is conserved to variable levels in several types of fungi such as Aspergillus oryzae (Tominaga et al., 2006), Emericella astellata, Aspergillus ochraceoroseus (Cary et al., 2005), Aspergillus versicolor (Viegas et al.,

Table 1. Maximum aflatoxin concentration allowed in foodstuffs by regulations some countries.

\begin{tabular}{|c|c|c|c|c|}
\hline Countries & Foodstuffs & Aflatoxins $^{1}$ & Limit levels of AFs $(\mu \mathrm{g} / \mathrm{kg})$ & References \\
\hline \multirow[t]{3}{*}{ China } & $\begin{array}{l}\text { Peanut and maize (their derivatives/products), } \\
\text { irradiated peanut, peanuts oil, }\end{array}$ & $\mathrm{AFB}_{1}$ & $\leq 20$ & $\begin{array}{l}\text { Moss, 2002; } \\
\text { Van Egmond and Jonker, } 2004\end{array}$ \\
\hline & $\begin{array}{l}\text { Edible vegetable oil, rice, and irradiated rice } \\
\text { Vinegar, beans fermented foods, starch products, } \\
\text { fermented wine, pastry biscuit, salad oil, soya } \\
\text { bean sauce, bread, fermented bean products, } \\
\text { butter cake, grain paste, other grains, both food } \\
\text { additives alpha-amylase and glucoamylase }\end{array}$ & $\begin{array}{l}\mathrm{AFB}_{1} \\
\mathrm{AFB}_{1}\end{array}$ & $\begin{array}{l}\leq 10 \\
\leq 5\end{array}$ & \\
\hline & Dairy product and milk & $\mathrm{AFM}_{1}$ & $\leq 0.5$ & \\
\hline $\begin{array}{l}\text { New Zealand/ } \\
\text { Australia }\end{array}$ & Tree nuts and peanuts & AFT & $\leq 15$ & Wu et al., 2016a \\
\hline \multirow[t]{2}{*}{ European Union } & $\begin{array}{l}\text { Dried fruit, groundnuts, cereals, nuts and all with } \\
\text { their products }\end{array}$ & $\mathrm{AFB}_{1}$ & $\leq 2$ & Juan et al., 2008; Moss, 2002 \\
\hline & & AFT & $\leq 4$ & \\
\hline Singapore & Nuts, corn, cereal and their products & AFT & $\leq 5$ & Wu et al., 2016a \\
\hline Brazil & Maize, peanuts and their product & AFT & $\leq 20$ & Bakırdere et al., 2012 \\
\hline Canada & Nuts and their products & AFT & $\leq 15$ & Van Egmond and Jonker, 2004 \\
\hline South Africa & All foods & $\begin{array}{l}\mathrm{AFB}_{1} \\
\mathrm{AFT}\end{array}$ & $\begin{array}{l}\leq 5 \\
\leq 10\end{array}$ & Wu et al., 2016a \\
\hline USA & All kinds of food & AFT & $\leq 20$ & Liu et al., 2006b \\
\hline Japan & All kinds of food & $\mathrm{AFB}_{1}$ & $\leq 10$ & Ding et al., 2012 \\
\hline \multirow[t]{4}{*}{ Turkey } & $\begin{array}{l}\text { Peanut and other nuts, hazelnut, spices, dried } \\
\text { fruits oily seed and their products }\end{array}$ & $\mathrm{AFB}_{1}$ & $\leq 5$ & $\begin{array}{l}\text { Set and Erkmen, 2010; } \\
\text { Van Egmond and Jonker, } 2004\end{array}$ \\
\hline & & AFT & $\leq 10$ & \\
\hline & Cereals and their product & $\mathrm{AFB}_{1}$ & $\leq 2$ & \\
\hline & & AFT & $\leq 4$ & \\
\hline \multirow[t]{2}{*}{ Mexico } & Cereals and products & AFT & $\leq 20$ & Van Egmond and Jonker, 2004 \\
\hline & Corn flour for tortilla & AFT & $\leq 12$ & \\
\hline Malaysia & All types of food & AFT & $\leq 35$ & Liu et al., 2006b \\
\hline India & All types of food & $\mathrm{AFT}, \mathrm{AFM}_{1}$ & $\leq 30$ & Moss, 2002 \\
\hline
\end{tabular}


2013), and other vaguely related fungi, such as Dothistroma (Zhang et al., 2007). Although all these fungi have high levels of similarities in terms of conservation of their gene cluster, it was revealed that only Aspergilli can produce both aflatoxin and its allied sterigmatocystin (Amaike and Keller, 2011). Some of the aforementioned species have also been identified in China. For example, a study by Sun et al. (2017) indicated that $A$. versicolor and $A$. nidulans are the major mycotoxigenic fungi contaminating rice in Henan and Hubei provinces of China. The study by Zhang et al. (2017) isolated aflatoxin-producing Aspergillus species from 600 soil samples obtained from the 4 agro-ecological areas in China. From these soil samples, 344 Aspergillus strains were isolated. Among these strains, 20 (5.8\%) were found to be $A$. parasiticus and the remaining 324 strains (94.2\%) were found to be A. flavus. Thus, A. flavus was the most predominant species among the aflatoxigenic fungal samples collected from all the districts. A previous study by Gao et al. (2007) suggests that A. flavus is the primary source of the fungal infection in maize, and responsible for more than $99 \%$ of all the contamination cases that have been recorded so far in the northeast region of the country.

A recent study examined and quantified several types of fungal species present in drinking water. Samples were collected from 15 different sites and water systems in the city of Xiamen, China. The authors showed that the predominant fungi were Aspergillus spp., Phialophora spp., Fusarium spp., Trichoderma spp., Pencillium spp., and included $A$. flavus and $A$. parasiticus, the last two being the major aflatoxigenic fungi identified in their study (Al-Gabr et al., 2014). The recent study by Su et al. (2018) investigated the occurrence of fungi in root herbs focusing on fungi that are capable to produce aflatoxins. They collected 48 samples of eight root herbs from Yulin and Anguo medicinal products markets and found that all these samples were contaminated with fungi, whereby a total of 1,844 isolates were detected. All these fungi belonged to 24 different genera including Aspergillus, Arthrinium, Alternaria, Chaetomium, Coprinellus, Mycocladus, Cladosporium, Fusarium, Lichtheimia, Wallemia, Hyphopichia, Myceliophthora, Paecilomyces, Eurotium, Penicillum, Pichia, Phanerochaete, Pestalotiopsis, Phoma, Rhizopus, Trichoderma, Syncephalastrum, Mucor and Trichosporon. The study further revealed that both the Penicillium and Aspergillus genera included potential toxigenic species with an occurrence of 25 and 10\%, respectively. From all tested samples of eight root herbs (48 samples), the occurrence of aflatoxins was found to be $37.50 \%$, whereby the species with great potential of aflatoxin production were $A$. flavus and $A$. parasiticus. $\mathrm{AFB}_{1}$ and $\mathrm{AFB}_{2}$ are normally produced by $A$. flavus toxigenic strains, while most of $A$. parasiticus strains produce all four aflatoxin types (Kew, 2013). The two other aflatoxins $\mathrm{AFM}_{1}$ and $\mathrm{AFM}_{2}$ are produced by hydroxylation of $\mathrm{AFB}_{1}$ and $\mathrm{AFB}_{2}$, respectively, and they are linked to casein proteins (Bianco et al., 2012; Motawee and McMahon, 2009; Prandini et al., 2009).

In general, different aflatoxins and aflatoxin producing fungal species occur in several regions of china, and most of them can easily be isolated and identified from samples. Table 2 lists the major aflatoxigenic Aspergillus species and the types of aflatoxins they produce as well as properties of aflatoxins.

\section{Conditions for aflatoxins production in China}

Aflatoxin production is influenced by several factors, including chemical, biological and physical ones. The criticality of the chemical factors is mostly based on the nature of the substrate being involved as well as the composition of the air. The physical factors, however, consist of moisture and temperature, whereas the biological factors include those relating to the host species (Al-Gabr et al., 2013; Liu et al., 2017; Yin et al., 2008). Some of the factors that influence aflatoxin production in China were studied by Lu et al. (2010). They found that numerous enzymes, such as peroxidases, dehydrogenases, cyclases, oxidoreductase and methyltransferases have a key function in aflatoxin biosynthesis. The action of these enzymes could directly affect the aflatoxin yield. Alternatively, $\mathrm{Yu}$ (2012) indicated that the most essential environmental factors are the plant metabolites, water activity, temperature, nitrogen and carbon source. It was also confirmed that the environmental conditions play an important role in aflatoxin contamination during, before and after harvest of crops (Ding et al., 2012). A study conducted by Liu et al. (2016) analysed the effects of several nutrients on $\mathrm{AFB}_{1}$ production by fungi. The authors found that some nutrients, i.e. vitamins, amino acids, minerals (such as zinc), energy source (especially in the form of starch) and fatty acids are also essential for aflatoxin production. These findings were supported by those from an earlier study conducted by Ma et al. (2015) who already indicated that substrate content and the composition of nutrients could be the key factor affecting $\mathrm{AFB}_{1}$ production. Another research added that aflatoxin production in water can also be affected by different environmental factors, such as nitrogen, micronutrients, macronutrients, carbon, $\mathrm{pH}$ and temperature (Al-Gabr et al., 2013).

The temperature range for aflatoxin production by the highly aflatoxin-producing fungi $A$. parasiticus and $A$. flavus species is between 12 to $41^{\circ} \mathrm{C}$, whereby the optimum production occurs in the range between 25 and $32^{\circ} \mathrm{C}$. Thus, production of aflatoxins decreases when the temperatures approach $37^{\circ} \mathrm{C}$ (Dwivedi et al., 2013; O'Brian et al., 2007; $\mathrm{Yu}, 2012)$. However, the rate of aflatoxins biosynthesis is higher when the temperature is greater than $27^{\circ} \mathrm{C}$ and when moisture and humidity levels are above 14 and $62 \%$, respectively (Royes and Yanong, 2002). It has also been 
Table 2. Aspergillus species and aflatoxins properties. ${ }^{1}$

\begin{tabular}{|c|c|c|c|c|c|c|c|c|c|c|}
\hline \multirow{2}{*}{$\begin{array}{l}\text { Type of } \\
\text { aflatoxin }\end{array}$} & \multirow{2}{*}{$\begin{array}{l}\text { Major producing } \\
\text { species/metabolites }\end{array}$} & \multirow{2}{*}{$\begin{array}{l}\text { Mol. } \\
\text { Formula }\end{array}$} & \multirow{2}{*}{$\begin{array}{l}\text { Mol. Wt } \\
(\mathrm{g} / \mathrm{mol})\end{array}$} & \multirow{2}{*}{$\begin{array}{l}\text { Melting point } \\
\left({ }^{\circ} \mathrm{C}\right)\end{array}$} & \multirow{2}{*}{$\begin{array}{l}\text { Optical rotation } \\
\text { [a]D }\end{array}$} & \multirow[t]{2}{*}{ Description } & \multicolumn{2}{|l|}{ UV absorption } & \multirow{2}{*}{$\begin{array}{l}\text { Fluorescence } \\
\text { emission }(m \mu)\end{array}$} & \multirow{2}{*}{ References } \\
\hline & & & & & & & $\lambda_{\max }(\mathrm{nm})$ & $\varepsilon(\mathrm{I} / \mathrm{mol} \mathrm{Cm})$ & & \\
\hline $\mathrm{AFB}_{1}$ & $\begin{array}{l}\text { A. flavus; } A \text {. } \\
\text { parasiticus; } A \text {. nomius }\end{array}$ & $\mathrm{C}_{16} \mathrm{H}_{12} \mathrm{O}_{6}$ & 312.3 & $\begin{array}{l}\text { 268-269 } \\
\text { decomposed }\end{array}$ & $\begin{array}{l}-558^{\circ} \text { in } \\
\text { chloroform }\end{array}$ & $\begin{array}{l}\text { Change from colourless to } \\
\text { pale-yellow crystals. Emits } \\
\text { strong blue fluorescence } \\
\text { under UV light. }\end{array}$ & $265 ; 223 ; 362$ & $\begin{array}{l}13,400 \\
25,600 \\
21,800\end{array}$ & 425 & $\begin{array}{l}\text { Andersen et al., 2012; Cole } \\
\text { et al., 2003; Humans et al., } \\
\text { 2002; lqbal et al., 2017; } \\
\text { Kumar, 2018; O'Neil et al., } \\
2001\end{array}$ \\
\hline $\mathrm{AFB}_{2}$ & $\begin{array}{l}\text { A. flavus; } A \text {. } \\
\text { parasiticus; } A \text {. nomius }\end{array}$ & $\mathrm{C}_{17} \mathrm{H}_{14} \mathrm{O}_{6}$ & 314.3 & $\begin{array}{l}\text { 286-289 } \\
\text { decomposed }\end{array}$ & $\begin{array}{l}-492^{\circ} \text { in } \\
\text { chloroform }\end{array}$ & $\begin{array}{l}\text { Colourless to pale-yellow } \\
\text { crystals. Emits blue } \\
\text { fluorescence under UV liaht. }\end{array}$ & $265 ; 363$ & $\begin{array}{l}11,700 \\
23,400\end{array}$ & 425 & $\begin{array}{l}\text { Andersen et al., 2012; Cole } \\
\text { et al., 2003; lqbal et al., } \\
\text { 2017: Kumar. } 2018\end{array}$ \\
\hline $\mathrm{AFG}_{1}$ & $\begin{array}{l}\text { A. parasiticus; } A \text {. } \\
\text { flavus; A. nomius; } \\
\text { A. niger }\end{array}$ & $\mathrm{C}_{17} \mathrm{H}_{12} \mathrm{O}_{7}$ & 328.3 & $\begin{array}{l}\text { 244-246 } \\
\text { decomposed }\end{array}$ & $\begin{array}{l}-556^{\circ} \text { in } \\
\text { chloroform }\end{array}$ & $\begin{array}{l}\text { Colourless to pale-yellow } \\
\text { crystals. Emits strong green } \\
\text { fluorescent under UV light. }\end{array}$ & $\begin{array}{l}264 ; 257 \\
362 ; 243\end{array}$ & $\begin{array}{l}10,000 \\
9,900 \\
16,100 \\
11,500\end{array}$ & 450 & $\begin{array}{l}\text { Andersen et al., 2012; Cole } \\
\text { et al., 2003; lqbal et al., } \\
\text { 2017; Kumar, 2018; O'Neil } \\
\text { et al., } 2001\end{array}$ \\
\hline $\mathrm{AFG}_{2}$ & $\begin{array}{l}\text { A. parasiticus; } A \text {. } \\
\text { flavus; } A \text {. nomius; } \\
\text { A. niger }\end{array}$ & $\mathrm{C}_{17} \mathrm{H}_{14} \mathrm{O}_{7}$ & 330.3 & $\begin{array}{l}\text { 237-240 } \\
\text { decomposed }\end{array}$ & $\begin{array}{l}-473^{\circ} \text { in } \\
\text { chloroform }\end{array}$ & $\begin{array}{l}\text { Colourless to pale-yellow } \\
\text { crystals. Strong green-blue } \\
\text { fluorescence under UV light. }\end{array}$ & $265 ; 363$ & $\begin{array}{l}9,700 \\
21,000\end{array}$ & 450 & $\begin{array}{l}\text { Andersen et al., 2012; Cole } \\
\text { et al., 2003; lqbal et al., } \\
\text { 2017; Kumar, 2018; O'Neil } \\
\text { et al., } 2001\end{array}$ \\
\hline $\begin{array}{l}\mathrm{AFM}_{1} \text { (metabolite } \\
\text { of } \mathrm{AFB}_{1} \text { ) }\end{array}$ & $\begin{array}{l}\text { A. flavus; } A \text {. } \\
\text { parasiticus; } A \text {. nomius }\end{array}$ & $\mathrm{C}_{17} \mathrm{H}_{12} \mathrm{O}_{7}$ & 328.3 & 299 decomposed & $\begin{array}{l}-280^{\circ} \text { in } \\
\text { dimethylformamide }\end{array}$ & $\begin{array}{l}\text { Colourless to pale-yellow } \\
\text { crystals. Emits strong blue- } \\
\text { violet fluorescence under }\end{array}$ & $357 ; 267 ; 244$ & $\begin{array}{l}19,950 \\
12,950 \\
9,100\end{array}$ & 430 & $\begin{array}{l}\text { Andersen et al., 2012; Cole } \\
\text { et al., 2003; Holzapfel et } \\
\text { al., 1966; lqbal et al., 2017; }\end{array}$ \\
\hline $\begin{array}{l}\mathrm{AFM}_{2} \text { (metabolite } \\
\text { of } \mathrm{AFB}_{2} \text { ) }\end{array}$ & $\begin{array}{l}\text { A. flavus; } A \text {. } \\
\text { parasiticus; } \text { A. nomius }\end{array}$ & $\mathrm{C}_{17} \mathrm{H}_{14} \mathrm{O}_{7}$ & 330.3 & 293 decomposed & $\mathrm{N} / \mathrm{A}$ & $\begin{array}{l}\text { UV light. } \\
\text { Colourless to pale-yellow } \\
\text { crystals. Emits strong violet } \\
\text { fluorescence under UV light. }\end{array}$ & $357 ; 264 ; 244$ & $\begin{array}{l}21,250 \\
11,650 \\
10,100\end{array}$ & $\mathrm{~N} / \mathrm{A}$ & $\begin{array}{l}\text { Stubblefield et al., } 1972 \\
\text { Andersen et al., 2012; } \\
\text { Holzapfel et al., 1966; } \\
\text { Stubblefield et al., } 1972\end{array}$ \\
\hline
\end{tabular}


shown that different levels of water activity $(0.99$ and 0.93 $\mathrm{a}_{\mathrm{w}}$ ) can affect both growth and aflatoxin production in A. flavus at $37^{\circ} \mathrm{C}$ (Zhang et al., 2014). Previous studies on A. parasiticus revealed that the combination of water activity $\left(0.90 \sim 0.99 \mathrm{a}_{\mathrm{w}}\right)$ and temperature $\left(17 \sim 42{ }^{\circ} \mathrm{C}\right)$ affects aflatoxin biosynthesis (Schmidt-Heydt et al., 2010). A study conducted by Liu et al. (2017) on A. flavus showed that fungal growth in shelled peanuts and its aflatoxin production were also affected by the combination of temperature and water activity within a similar range of $15 \sim 42{ }^{\circ} \mathrm{C}$ and $0.85 \sim 0.99 \mathrm{a}_{\mathrm{w}}$, respectively. However, the optimal growth conditions for A. flavus were found to be at $37^{\circ} \mathrm{C}$ with $0.98 \mathrm{a}_{\mathrm{w}}$, while those for $\mathrm{AFB}_{1}$ production were found to be at $25 \sim 28^{\circ} \mathrm{C}$ with $0.96 \mathrm{a}_{\mathrm{w}}$, and $33 \sim 37^{\circ} \mathrm{C}$ with $0.92 \mathrm{a}_{\mathrm{w}}$.

All these studies together show that environmental conditions, substrates, hosts and fungal species interact with each other, creating different conditions for aflatoxin production in different countries, including China (Figure 1).

\section{Distribution of aflatoxin contamination in China}

Spores of aflatoxigenic fungi are mainly found and/ or distributed in the dust, air, water and soil, whereby higher concentrations of aflatoxins have been particularly reported in contaminated grain maize, peanuts, wheat and decomposing organic substances (Guan et al., 2011a). The aforementioned problems have recently been verified in studies by Sun et al. (2011), Tumukunde et al. (2019), and Wang and Liu (2007b) who indicated that aflatoxins were found contaminating Chinese seed crops, such as peanuts, rice, cotton, beans, wheat and maize. These authors further reiterated that the massive infections caused by aflatoxins are the most important cause for the immense losses in agricultural commodities suffered by numerous farmers in China. The aforesaid crop seeds contamination has been identified in several regions of China. However, the levels of aflatoxin distribution vary dramatically in different areas because agricultural systems and environmental conditions differ from one location to another (Table 3).

Aflatoxin contamination has been a great issue in different counties in southern China. For example, in Chongzuo county situated in the southern region of Guangxi province, aflatoxins have been found at high levels and the people are highly exposed to $\mathrm{AFB}_{1}$. In this county, the relative humidity, average annual temperature, rainy days and precipitation are $79 \%, 21.9^{\circ} \mathrm{C}, 148$ days, and $1,311 \mathrm{~mm}$, respectively. Based on the analysis of climatic conditions conducted for over a 10-year period in Chongzuo county, more than 150 days/ year have temperatures greater than $30{ }^{\circ} \mathrm{C}$ and a relative humidity over $80 \%$, which are the optimum conditions supporting the growth of Aspergillus species and production of related mycotoxins, respectively. Therefore, the high level of aflatoxin production is due to environmental conditions in this region (Li et al., 2001). The study (Liao et al., 2009) indicates that peanuts produced in the southern regions

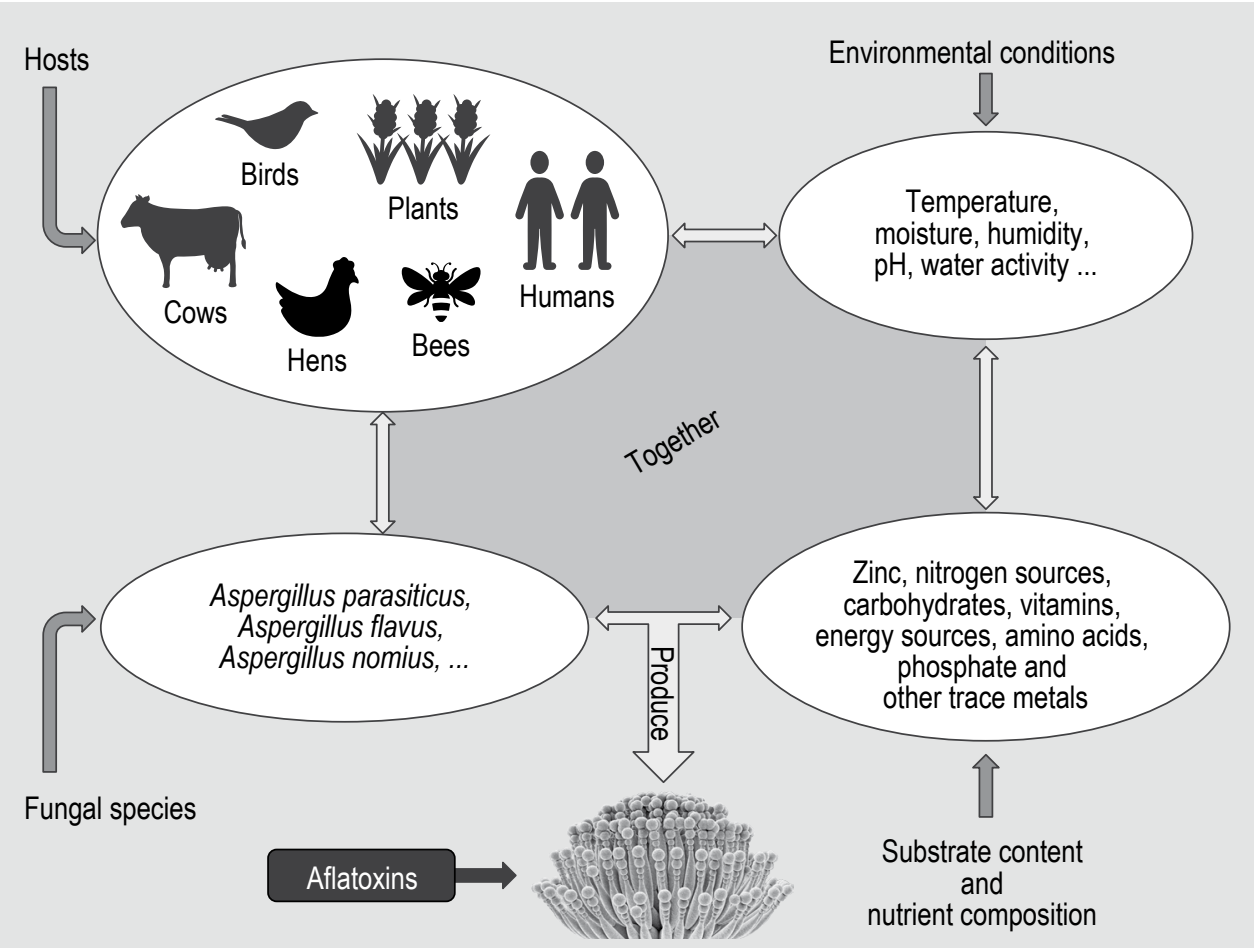

Figure 1. Environmental conditions vis-a-vis aflatoxins production. 
Table 3. Aflatoxin contamination in foodstuffs in China. ${ }^{1}$

\begin{tabular}{|c|c|c|c|c|c|c|c|c|c|c|c|}
\hline \multirow{2}{*}{$\begin{array}{l}\text { Food } \\
\text { type }\end{array}$} & \multirow[t]{2}{*}{ Location } & \multirow[t]{2}{*}{ Origin } & \multirow{2}{*}{$\begin{array}{l}\text { Aflatoxin } \\
\text { detected }\end{array}$} & \multirow{2}{*}{$\begin{array}{l}\text { No. of } \\
\text { examined } \\
\text { samples }\end{array}$} & \multirow{2}{*}{$\begin{array}{l}\text { Occurrence } \\
\%\end{array}$} & \multirow{2}{*}{$\begin{array}{l}\text { Level range of } \\
+ \text { ve sample } \\
(\mu \mathrm{g} / \mathrm{kg})\end{array}$} & \multirow{2}{*}{$\begin{array}{l}\text { Average no. of } \\
+ \text { ve samples } \\
\mu \mathrm{g} / \mathrm{kg}\end{array}$} & \multirow{2}{*}{ Methods } & \multicolumn{2}{|c|}{ Mean estimated intakes } & \multirow[t]{2}{*}{ References } \\
\hline & & & & & & & & & children & adults & \\
\hline Peanut & $\begin{array}{l}12 \text { provinces: Shandong, } \\
\text { Liaoning, Henan, Hebei, } \\
\text { Jiangsu, Anhui, Jiangxi, } \\
\text { Hubei, Hunan, Guangdong, } \\
\text { Guangxi, Fujian }\end{array}$ & $\begin{array}{l}\text { agro-ecological } \\
\text { zones }\end{array}$ & $\mathrm{AFB}_{1}$ & 1,040 & 25 & $0.01-720$ & 2.13 & $\begin{array}{l}\text { HPLC and } \\
\text { immunoaffinity } \\
\text { columns }\end{array}$ & $\begin{array}{l}0.218-0.222 \mathrm{ng} / \\
\mathrm{kg}(\mathrm{BW}) / \text { day }\end{array}$ & $\begin{array}{l}0.106-0.108 \mathrm{ng} / \\
\mathrm{kg}(\mathrm{BW}) / \text { day }\end{array}$ & Ding et al., 2012 \\
\hline \multirow[t]{3}{*}{$\begin{array}{l}\text { Peanut } \\
\text { Maize }\end{array}$} & $\begin{array}{l}1 \text { Province: Nanjing } \\
8 \text { provinces: Chongqing, }\end{array}$ & $\begin{array}{l}\text { markets } \\
\text { markets }\end{array}$ & $\begin{array}{l}\mathrm{AFB}_{1} \\
\mathrm{AFB}_{1}\end{array}$ & $\begin{array}{l}20 \\
74\end{array}$ & $\begin{array}{l}80 \\
62.16\end{array}$ & $\begin{array}{l}0-58.25 \\
0.14-970.32\end{array}$ & $\begin{array}{r}0.72 \\
29.05\end{array}$ & $\begin{array}{l}\text { ELISA } \\
\text { HPLC }\end{array}$ & $\begin{array}{l}\mathrm{N} / \mathrm{A} \\
\mathrm{N} / \mathrm{A}\end{array}$ & $\begin{array}{l}\text { N/A } \\
\text { N/A }\end{array}$ & $\begin{array}{l}\text { Xu et al., } 2006 \\
\text { Wang and Liu, 2007b }\end{array}$ \\
\hline & Fujian Guangxi, Zhejiang, & & $\mathrm{AFB}_{2}$ & & 55.41 & $0.02-128.04$ & 2.00 & & & & \\
\hline & $\begin{array}{l}\text { Hubei, Shanghai, } \\
\text { Guangdong, Jiangsu }\end{array}$ & & $\mathrm{AFG}_{1}$ & & 12.16 & $0.36-4.76$ & 0.97 & & & & \\
\hline Yogurt & 31 provinces & $\begin{array}{l}\text { retail store and } \\
\text { supermarkets }\end{array}$ & $\mathrm{AFM}_{1}$ & 178 & 4.49 & $\mathrm{~N} / \mathrm{A}$ & 27.10 & ELISA & $\begin{array}{l}0.327-0.353 \mathrm{ng} / \\
\mathrm{kg}(\mathrm{BW}) / \text { day }\end{array}$ & $\begin{array}{l}0.023-0.382 \mathrm{ng} / \\
\mathrm{kg}(\mathrm{BW}) / \text { day }\end{array}$ & Guo et al., 2013 \\
\hline \multirow{4}{*}{ Maize } & & & & $\begin{array}{r}233 \\
87\end{array}$ & $\begin{array}{l}48.07 \\
99\end{array}$ & & $\begin{array}{c}21.49 \\
88\end{array}$ & & & & \\
\hline & 6 provinces: Hainan, & $\begin{array}{l}\text { Teed companies } \\
\text { granaries, farmer }\end{array}$ & $\begin{array}{l}\mathrm{AFB}_{1} \\
\mathrm{AFT}\end{array}$ & $\begin{array}{r}81 \\
370\end{array}$ & 63.5 & $\begin{array}{l}0.0-183 \\
0.030-21.0\end{array}$ & $\begin{array}{l}8.8 \\
0.65\end{array}$ & ELISA & $\mathrm{N} / \mathrm{A}$ & N/A & Fu et al., 2014 \\
\hline & Guangxi, Guangdong, & stores and & $\mathrm{AFB}_{1}$ & & 63.5 & $0.030-20.0$ & 0.60 & & & & \\
\hline & Liaoning, Heilongjiang, Jilin & markets & $\mathrm{AFB}_{2}$ & & 17.6 & $0.0-1.6$ & 0.15 & DLLME-HPLC & $\mathrm{N} / \mathrm{A}$ & $\mathrm{N} / \mathrm{A}$ & Lai et al., 2015a \\
\hline $\begin{array}{l}\text { Rice } \\
\text { Peanut }\end{array}$ & $\begin{array}{l}6 \text { provinces: Sichuan, } \\
\text { Hubei, Anhui, Hunan, } \\
\text { Jiangxi, Jiangsu }\end{array}$ & $\begin{array}{l}\text { fields in Yangtze } \\
\text { River ecological } \\
\text { region }\end{array}$ & $\mathrm{AFB}_{1}$ & 2,983 & 31 & $0-92.467$ & 7.101 & HPLC-FLD & $\begin{array}{l}0.777-0.790 \mathrm{ng} / \\
(\mathrm{kg} \cdot \mathrm{d})\end{array}$ & $\begin{array}{l}0.343-0.349 \mathrm{ng} / \\
(\mathrm{kg} \cdot \mathrm{d})\end{array}$ & Ding et al., 2015 \\
\hline Maize & Beijing & animal farms & $\begin{array}{l}\mathrm{AFB}_{1} \\
\mathrm{AFB}_{2} \\
\mathrm{AFG}_{1}\end{array}$ & 22 & $\begin{array}{l}50 \\
9.1 \\
4.5 \\
91\end{array}$ & $\begin{array}{l}59 \\
12 \\
0.5 \\
0.5\end{array}$ & $\begin{array}{l}6.0 \\
0.6 \\
0.0\end{array}$ & HPLß & $\mathrm{N} / \mathrm{A}$ & N/A & Fan et al., 2012 \\
\hline \multirow{4}{*}{$\begin{array}{l}\text { Rice } \\
\text { Maize } \\
\text { Maize }\end{array}$} & Liaoning & barns & $\begin{array}{l}\mathrm{AFG}_{2} \\
\mathrm{AFG}_{1} \\
\mathrm{AFT}\end{array}$ & $\begin{array}{l}36 \\
73\end{array}$ & $\begin{array}{r}9.1 \\
91.7 \\
2.8\end{array}$ & $\begin{array}{l}0.5 \\
\text { N/A } \\
\text { N/A }\end{array}$ & $\begin{array}{l}0.0 \\
0.88 \\
0.99\end{array}$ & HPLC-FLD & N/A & $\mathrm{N} / \mathrm{A}$ & Liu et al., 2006b \\
\hline & Guangxi & farmers & $\mathrm{AFB}_{1}$ & 40 & 85 & $9-2,496$ & 460 & HPLC & $\mathrm{N} / \mathrm{A}$ & $3.68 \mu \mathrm{g} / \mathrm{kg}$ & Li et al., 2001 \\
\hline & & & $\mathrm{AFB}_{2}$ & & 65 & $11-320$ & 82 & & & (BW)/day & \\
\hline & & & $\mathrm{AFG}_{1}$ & & 45 & $12-21$ & 15 & & & & \\
\hline
\end{tabular}

${ }^{1} \mathrm{~N} / \mathrm{A}=$ not available; $\mathrm{BW}=$ body weight; HPLC-FLD = high-performance liquid chromatography with fluorescence detection; DLLME-HPLC = dispersive liquid-liquid microextraction with high performance liquid chromatography; $H P L C=$ high-pressure liquid chromatography; ELISA = enzyme-linked immunosorbent assay; $A_{F} B_{1}=$ aflatoxin $B_{1} ; A F B_{2}=$ aflatoxin $B_{2} ; A F G_{1}=$ aflatoxin $G_{1} ; A F G_{2}=$ aflatoxin $G_{2} ; A_{F T}=$ total aflatoxins $\left(\mathrm{AFB}_{1}+\mathrm{AFB}_{2}+\mathrm{AFG}_{1}+\mathrm{AFG}_{2}\right.$. 
of China are usually more contaminated by aflatoxins than those in the northern parts. This was also confirmed in a series of studies that were conducted between 2002 and 2008 on aflatoxin contamination in 20 provinces around the country. More than 1000 study cases were conducted, and results showed that aflatoxins were present in many provinces and in most of the tested samples, whereby the overall level of aflatoxins contamination in the southern region of China was greater than that in the northern part. The most severe contamination cases were found in Guangxi province and the humid and hot southern climate might have been the main reasons for these higher rates of contaminations (Wu et al., 2016a; Zhang et al., 2011b). Some studies correlate the incidence of hepatocellular carcinoma (HCC) cancer occurring in China, Southeast Asia and sub-Saharan Africa regions, where populations experience high hepatitis $\mathrm{B}$ virus (HBV) incidence, to the largely unmanageable aflatoxin exposure in foodstuff (Liu and Wu, 2010; Yu et al., 2013). Dietetic aflatoxin exposure and $\mathrm{HBV}$ are known to be the leading etiological causes of HCC (Wang et al., 2001).

Several studies revealed that the incidence and conditions of aflatoxin production in the northern part of China are lower than those in the southern part of China (Gao et al., 2011; Gong et al., 2017; Ma et al., 2011). A research conducted in Beijing, located in northern part, to evaluate and analyse aflatoxin contamination demonstrated that $\mathrm{AFB}_{1}$ is distributed in Beijing's feeds and feedstuffs (Fan et al., 2012). A conducted survey by Liu et al. (2012) revealed that the amount of aflatoxin contamination in different samples was low in Hebei province, whereby the identified level of aflatoxins in most samples was less than $0.5 \mu \mathrm{g} / \mathrm{kg}$. These results were recently corroborated by Gong et al. (2016) who compared, investigated and indicated that the maximum positive value, average content and incidence of mycotoxins in the northern part of China are lower in contrast to those in the southern part. Although many studies indicated that the levels of aflatoxins in the northern region of the country are below the maximum levels, the risk of exposure should not be ignored in this region due to frequent contamination. Several cases of aflatoxins have been also identified in central area of China (Gao et al., 2011; Wu et al., 2016b). Rainfall and temperature are among the important climatic factors that affect the production of aflatoxins in China (Diao et al., 2015; Li et al., 2014). Consequently, the study by Wu et al. (2016b) reported that aflatoxin contaminated feeds in Henan province located in the centre of China were found to be a great issue in this region. This province exhibits plentiful rainfall and long periods of increased temperature simultaneously. Gao et al. (2011) collected maize samples in order to analyse the levels of aflatoxin production in 6 provinces of China (central, southern and northern parts) and noted that the contamination levels were significantly different within these provinces. They found that the contamination levels in the southern area were more prevalent than in the northern and central areas. This clearly indicates that aflatoxin contaminated feed and food are found in different provinces of China, which might result in several problems including food shortage, health issues and economic losses among others.

\section{Commodities contaminated by aflatoxins in China}

Aflatoxin contaminated food often leads to serious health issues when ingested by humans and animals in significantly low-level doses on a daily basis (Sun et al., 2013; Wang et al., 2009). Specifically, long-term aflatoxin exposure leads to a decreased efficiency of immunisation and stunted growth in children, whereas cytochrome 4450 enzymes activating $\mathrm{AFB}_{1}$ in the liver will result in $\mathrm{AFB}_{1}$-8,9-epoxide, leading to carcinogenic effects in the kidney (Chen et al., 2006). These findings are supported by Yu (2012) and Wang et al. (2015) who reported that $\mathrm{AFB}_{1}$ is a potent carcinogen in both animals and humans, whereby chronic exposure of these living beings could result in proliferation of the bile duct, suppressed the immune response, hepatomas, centrilobular necrosis, malnutrition, fatty infiltration of the liver, and hepatic lesions. Due to these health risks, grain storage conditions and agriculture practices have been improved in the country. This has contributed to a great reduction in the occurrence of aflatoxins. A brief description of the present levels of aflatoxins in different crops and the estimated exposure of humans to this mycotoxin is discussed in this section and summarised in Table 3.

Aflatoxin contaminations are commonly found in Chinese maize. For example, studies performed in Guangxi province assessed the risk of $\mathrm{AFB}_{1}$ contamination on human primary HCC based on the concentration level $(9 \sim 2,496 \mu \mathrm{g} /$ $\mathrm{kg}$ ) from maize samples in high incidence areas in this province (Ding et al., 2012; Li et al., 2001). They realised that residents in this province eat maize and its derivatives as their staple food (400 g/day/person). The estimated exposure to $\mathrm{AFB}_{1}$ per individual ranged from 0.07-19.96 $\mu \mathrm{g} / \mathrm{kg} \mathrm{BW} /$ day, indicating that maize and its derivatives are a major contributor to $\mathrm{AFB}_{1}$ exposure in this province. These results corroborate with those reported by Wang and Liu (2007a). The authors further indicated that peanuts, peanut oil and rice were other major contributors to aflatoxin exposure. The occurrence of aflatoxins in maize collected from farmers in Guangxi province in the low and high incidence regions for human cancer was examined, and they found that $\mathrm{AFB}_{1}$ was the main toxin in terms of frequency and quantity. The incidence of $\mathrm{AFB}_{1}$ was $85 \%$ and its contamination levels were in the range of $9 \sim 2,496 \mu \mathrm{g} / \mathrm{kg}$. Differences in concentration of $\mathrm{AFB}_{1}, \mathrm{AFB}_{2}$ and $\mathrm{AFG}_{1}$ in maize were also found (Table 3 ). Also, the average estimated daily intake of $\mathrm{AFB}_{1}$ from maize for adults was $3.68 \mu \mathrm{g} / \mathrm{kg}$ (BW)/day (Li et al., 2001). In another research conducted 
by Gao et al. (2011), the authors examined $\mathrm{AFB}_{1}, \mathrm{AFB}_{2}$, $\mathrm{AFG}_{1}$ and $\mathrm{AFG}_{2}$ contamination in maize obtained from different provinces of China. They collected 279 samples in total and found that $76 \%$ of them were positive for aflatoxin contamination.

Peanuts are an important food crop and oil in China, and they are extensively grown in most provinces of the country. Currently, China is the largest country in the world in terms of annual peanut consumption, international trade and production (Liao et al., 2009). However, aflatoxin contamination of Chinese peanuts has been found in different parts of the country. $\mathrm{AFB}_{1}$ was detected in $80 \%$ of peanut samples collected from different markets in Nanjing with an average concentration of $0.72 \mu \mathrm{g} / \mathrm{kg}$ (range 0-58.25 $\mu \mathrm{g} / \mathrm{kg}$ ) (Liao et al., 2009). To examine $\mathrm{AFB}_{1}$ distribution in various areas, contamination levels in crops and its effect on human health, Ding et al. (2012) collected 1,040 peanuts samples from different agro-economic zones in 12 provinces of China between 2009 and 2010. In their study, the authors analysed $\mathrm{AFB}_{1}$ using both immunoaffinity columns and HPLC methods, and found that $25 \%(0.01-720 \mu \mathrm{g} / \mathrm{kg})$ of the samples were contaminated. A recent study investigated the potential $\mathrm{AFB}_{1}$ and $\mathrm{AFB}_{2}$ production in rice grain by 127 strains of $A$. flavus isolated from rice grains collected thoughout China. Rice grains were inoculated with these strains and incubated for 21 days at $28^{\circ} \mathrm{C}$, and the results showed that $37 \%$ produced $\mathrm{AFB}_{1}$ and $\mathrm{AFB}_{2}$. The average yields of these isolates were 5,884 and $1,968 \mu \mathrm{g} / \mathrm{kg}$ for $\mathrm{AFB}_{1}$ and $\mathrm{AFB}_{2}$, respectively. Overall, most of the aflatoxigenic strains produced higher levels of $\mathrm{AFB}_{1}$ than $\mathrm{AFB}_{2}$ in rice (Lai et al., 2015b).

The occurrence of aflatoxin M (AFM) in both milk and milk powder has also been analysed. During the study by Qian et al. (1994), a total of 15 milk powder and 57 milk samples was examined, and the results showed that 27 and $74 \%$ were contaminated, respectively. The range of AFM was found to be $0.1-0.35$ and $0.025-0.95 \mathrm{pg} / \mathrm{l}$ in milk powder and milk, respectively (Qian et al., 1994). However, a current study on $\mathrm{AFM}_{1}$ mentioned that the risk associated with $\mathrm{AFM}_{1}$ in milk is quite low in China (Guo et al., 2013). In this study, $\mathrm{AFM}_{1}$ was detected in $4.49 \%$ of the yogurt and $48.07 \%$ of the milk samples, however, none of the samples were found to contain $\mathrm{AFM}_{1}$ above the recent regulation limit in China.

In the next sections, aflatoxin detection, prevention and control methods in China will be discussed, as well as the management strategies to prevent aflatoxicosis and aflatoxin-related diseases to consumers.

\section{Common methods to detect aflatoxins in China}

The identification and quantification of aflatoxin content in food and feed has been crucially important to ensure the safety of food in recent years (Krska et al., 2008; Xie et al., 2016). Studies indicate that both detection and identification of aflatoxins are achieved based on their light absorption and emission spectra (Wang, 2015). Several techniques have been developed to detect aflatoxins; the most common methods are thin layer chromatography (TLC), high-pressure liquid chromatography (HPLC), liquid chromatography coupled to mass spectrometry (LC/MS), enzyme-linked immunosorbent assay (ELISA), electrochemical immunosensors, and immunochromatography (ICG) techniques (Wacoo et al., 2014; Zhang et al., 2018a). A brief description of these methods is given below.

TLC is one of the oldest and popular separation methods used to detect aflatoxins in several food products. TLC was used for the first time by Iongh et al. in 1964. The method is capable of economically screening a significant number of samples (Fallah et al., 2011; Stroka et al., 2000). The level of aflatoxins present in the samples can be directly measured using TLC specimens under the UV-light radiation $365 \mathrm{~nm}$ (Lan et al., 2019). Since the aflatoxin discovery in 1961, the TLC method has been widely utilised for mycotoxin analysis and is currently still used in China (Ahmad et al., 2019; Ren et al., 2018; Yuan et al., 2019). However, due to the high demand for accurate data, both the quantification procedures and separation of this method have been gradually enhanced from TLC to the HPLC method (Zhang et al., 2018b). HPLC has been developed since the 1960s and is known as a method that provides a quick, accurate and repeatable platform to analyse aflatoxin levels in different agricultural commodities (Wang, 2015). Therefore, this method has been frequently used because of its advantages, such as suitability for automation, easy to use, reproducibility, ability to couple with various detectors, high sensitivity and high separation power (Bakırdere et al., 2012). Different detectors, which can be programmed, like the UV-visible absorption detector (Herzallah, 2009), diode array detector (Palmisano et al., 1989) and fluorescence detector (Jaimez et al., 2000) can be applied in HPLC during the identification and detection of aflatoxin based on the nature of analyte (Wacoo et al., 2014). Once chemical derivatization is carried out, small amounts of aflatoxin (as little as $0.1 \mu \mathrm{g} / \mathrm{kg}$ ) can be detected by HPLC fluorescence detector (HPLC-FLD) (Herzallah, 2009; Wang, 2015). Studies reported that the use of postcolumn derivatization technique in HPLC-FLD is an official and a frequently used technique in several countries (Ghali et al., 2009; Zhang et al., 2011b). Therefore, HPLC is the most frequently used method in China (Zhang et al., 2013) and, for instance, applied to determine aflatoxin levels in 
traditional Chinese medicines (Han et al., 2010; Ip and Che, 2006; Zhang et al., 2005).

ELISA is also a widely used technique for aflatoxin detection in agricultural commodities in China. The method is commonly used in the food and feed industries in order to identify aflatoxins content in food products (Li et al., 2009b; Pei et al., 2009; Wang et al., 2011). For this method, numerous ELISA kits are commercially available and based on the competitive immunoassay format (Sun et al., 2015; Zhang et al., 2018b). ELISA is a reproducible method and can be used to analyse numerous samples simultaneously (Wacoo et al., 2014; Zhang et al., 2018b). However, this method sometimes gives either false negative or false positive results due to the instability of enzymes and/or reaction conditions. As a result, the application of this method to analyse aflatoxin should be improved (Beltrán et al., 2011; Xie et al., 2016).

As stated before, HPLC combined with fluorescence detection is a commonly used technique. It gives accurate and fast detection for aflatoxins, but a tedious derivatization procedure for fluorescence improvement must be carried out in traditional HPLC methods. This problem could be successfully solved by coupling HPLC to mass spectrometry (LC-MS). The ionisation source is utilised as interface between mass spectrometer and liquid chromatography. Because the structural information of the involved analytes can be directly examined by mass spectrometer, the chemical derivatization of aflatoxins could be eliminated. Moreover, LC-MS methods exhibit high sensitivity. Therefore, the LC-MS method also allows multiple analysis of aflatoxins and is suitable for detection of aflatoxins in cereals and feed (Zheng et al., 2014; Zhu et al., 2010).

Immunochromatography is also among the methods which are used to detect aflatoxins in food in China (Xiulan et al., 2006; Zhang et al., 2011a). This technique is a type of immunoassay method which was developed in recent years for quick detection of an analyte. Thus, it is rapid and simple, and appropriate for both prescreening and analysis of more samples (Shim et al., 2007). Another method that has also been applied in China for aflatoxin quantification uses an electrochemical immunosensor (Linting et al., 2012; Liu et al., 2006a).

Additional methods are those that examine the preoccurrence of aflatoxins. This includes the development of an orbitrap Fusion Mass Spectrometry method for monitoring metabolites through the aflatoxin biosynthesis pathway. In this method, ultra-high-performance liquid chromatography combined with high-resolution mass spectroscopy (UHPLC-HRMS) technique is developed for aflatoxins identification. A reverse-phase chromatography column is subsequently used to separate metabolites in the aflatoxin pathway. For the analysis of these metabolites both high-energy collision-induced dissociation (HCD) and electrospray ionization (ESI) should be carried out with an Orbitrap Fusion mass spectrometer (Xie et al., 2018). Another technique is the development of a specific nanobody-polyclonal antibody sandwich ELISA for detection of the aflatoxin-producing fungi $A$. flavus and $A$. parasiticus in agricultural products (Wang et al., 2017). The comparison of all the above methods, with their advantages and disadvantages is summarised in Table 4.

\section{Control and management strategies for aflatoxins in China}

In China, several strategies have been developed to manage and control aflatoxins, which are grouped into different categories. Most methods used to prevent/control aflatoxin production include, but are not limited to: breeding for resistance, the use of genetic engineering, the use of biological control agents, control of environmental factors, field management practices, proper storage, chemoprevention, adsorption as well as detoxification techniques, and dietary change among others (Hamid et al., 2013; Liao et al., 2009). Moreover, the application of post-harvesting techniques for aflatoxin reduction, such as sorting, cleaning, fast and proper drying, post-harvest insect control, spraying and smoking of synthetic pesticides or botanicals were used as storage protectants (Guan et al., 2011b; Hell et al., 2010; Liao et al., 2009). A summary of these techniques/methods is described in this section.

Biological control of fungal development in the field is the potential technique to control toxins in China. Different species have been analysed for biological control of infection by aflatoxigenic fungi, including yeasts (Pichia anomala and Candida krusei), non-toxigenic Aspergillus strains and bacteria (Lactobacillus spp., Burkholderia spp., Ralstonia spp., Pseudomonas spp. and Bacillus subtilis) (Yin et al., 2008, 2009). Further studies highlighted the potential use of the bacterial strains for biological control of $\mathrm{AFB}_{1}$ in agriculture and food industries. Pseudomonas qingdaonensis strain $\mathrm{JJ}^{\mathrm{T}}$ as well as Myroides odoratimimus strain 3J2MO were found to have the ability to degrade $\mathrm{AFB}_{1}$ (Mwakinyali et al., 2019; Wang et al., 2019b). An earlier study found that Pseudomonas fluorescens strain 3JW1 had numerous effects, such as inhibition of $A$.flavus growth and $\mathrm{AFB}_{1}$ biosynthesis, but it is also able to degrade $\mathrm{AFB}_{1}$ (Yang et al., 2017).

Breeding for resistance and genetic engineering techniques are also used for aflatoxin control. These methods help crop breeding in the development of germplasm that is able to resist fungal growth or/and aflatoxin contamination (Guo et al., 2009; Liao et al., 2009). Field management practices for aflatoxin control are carried out using effective weed control mechanisms, fertilisers, diversity of resistant 
Table 4. Comparison between the main methods used to detect aflatoxins in China. ${ }^{1}$

\begin{tabular}{|c|c|c|c|}
\hline Method & Advantages & Disadvantages & References \\
\hline TLC & $\begin{array}{l}\text { Economical and fast } \\
\text { Detect several mycotoxins in one sample } \\
\text { More accurate compared to HPLC }\end{array}$ & $\begin{array}{l}\text { Requires prior preparation of sample } \\
\text { Need a trained/skilled operator } \\
\text { Not automatic and high chance to be } \\
\text { harmful to the operator }\end{array}$ & $\begin{array}{l}\text { Bakırdere et al., 2012; } \\
\text { Turner et al., 2009; } \\
\text { Wang et al., } 2015\end{array}$ \\
\hline HPLC & $\begin{array}{l}\text { Automatic } \\
\text { Easy to use, reproducibility } \\
\text { Able to couple with various detectors } \\
\text { High sensitive } \\
\text { High separation power }\end{array}$ & $\begin{array}{l}\text { High operating costs } \\
\text { Time-consuming } \\
\text { Pretreatment of the sample }\end{array}$ & $\begin{array}{l}\text { Bakırdere et al., 2012; } \\
\text { Xie et al., } 2016\end{array}$ \\
\hline LC-MS & $\begin{array}{l}\text { Suitable for multiple analysis } \\
\text { Simultaneous quantification and qualification }\end{array}$ & $\begin{array}{l}\text { Requires a skilled operator } \\
\text { Difficult } \\
\text { High cost }\end{array}$ & Zheng et al., 2014 \\
\hline ELISA & $\begin{array}{l}\text { Fast and sensitive analysis } \\
\text { Requires a small volume of sample for analysis } \\
\text { Many samples can be analysed simultaneously } \\
\text { ELISA kits are cheap and easy to use } \\
\text { No intrinsic health hazards associated with enzyme labels }\end{array}$ & $\begin{array}{l}\text { Requires multiple washing steps that can } \\
\text { at times prove lengthy and time-consuming } \\
\text { Sometimes gives false negative or false } \\
\text { positive results }\end{array}$ & $\begin{array}{l}\text { Pei et al., 2009; } \\
\text { Zhang et al., 2018b }\end{array}$ \\
\hline ICG & $\begin{array}{l}\text { Offers good sensitivity } \\
\text { User-friendly format } \\
\text { Short assay time/rapid } \\
\text { Durable stability to a broad range of climates } \\
\text { Cost-effectiveness } \\
\text { Can screen large numbers of samples } \\
\text { Does not require skilled analysts }\end{array}$ & $\begin{array}{l}\text { Single analyte analysis can pose a huge } \\
\text { potential problem from grave false positive } \\
\text { results } \\
\text { Lack of selectivity }\end{array}$ & $\begin{array}{l}\text { Shim et al., 2007; } \\
\text { Xiulan et al., 2006; } \\
\text { Zhang et al., 2011a }\end{array}$ \\
\hline $\begin{array}{l}\text { Electrochemical } \\
\text { immunosensor }\end{array}$ & $\begin{array}{l}\text { Stability } \\
\text { Good sensitivity } \\
\text { Repeatable } \\
\text { Simple } \\
\text { Necessity of a sample pre-treatment can be avoided }\end{array}$ & $\begin{array}{l}\text { Requires multiple washing steps that } \\
\text { can at times prove it lengthy and time- } \\
\text { consuming } \\
\text { Need a skilled operator }\end{array}$ & $\begin{array}{l}\text { Evtugyn and Hianik et } \\
\text { al., } 2019\end{array}$ \\
\hline
\end{tabular}

${ }^{1} \mathrm{TLC}=$ thin layer chromatograph; LC/MS = liquid chromatography coupled to mass spectrometry; ICG = immunochromatography.

crops, bird or insect control by pesticides, as well as by avoiding nutritional and drought stress (Choudhary and Kumari, 2010; Diao et al., 2015). In addition, timely planting and harvesting crops, as well as decrease of deep tillage practices, and in some cases elimination of the amount of inoculum that might be present in the topmost layer of the soil (Diao et al., 2015). Contamination can also be controlled by the construction of appropriate humidity proof storage facilities to shield the grains from infection and maintain favourable storage temperature (Hell et al., 2010; Liao et al., 2009; Zhang et al., 2011b).

Adsorption is another method to decrease aflatoxin contamination. Studies have shown that the harmful effect of aflatoxins on animals can be minimised by the addition of different types of nutrition adsorbent to the animal feed. The combination of some bacteria can lower the adsorption capacity of toxins in the intestinal tract of chickens, thereby reducing their biological activity in vivo and prevent liver cancer (Gratz et al., 2005; Wang et al., 2018). Specific changes in animal and human diets, for instance by eating chlorophyllin-rich foods, reduces the effects of aflatoxin exposure and minimises the risks of liver cancer, as well as the absorption of AFB 1 (Egner et al., 2001; Fahey et al., 2005; Versantvoort et al., 2005). Also, the frequent consumption of high-risk foods, like maize and groundnut, should be minimised by intake of a more varied diet, and use of a less risky staple food, such as sorghum and millet (Hell et al., 2008). The use of chemoprevention, i.e. daily ingestion of oltipraz or chlorophyllin and hydrated sodium calcium aluminosilicate anticaking agent into the diet, can help to decrease the effects of aflatoxins. The hydrated sodium calcium alumino-silicates reduce aflatoxin absorption by binding to the $\beta$-carbonyl portion of the aflatoxin molecules and hence prevent the aflatoxicosis (Chen et al., 2014; Ledoux 
et al., 1999). Regular decontamination of commodities from aflatoxins can be achieved either physically (through physical segregation, sorting, and/or flotation), chemically (with ammonia or calcium hydroxide), or microbiologically by including pro-biotics or lactic acid bacteria into the diet (Shu et al., 2018; Wang et al., 2018). Another strategy to control and prevent the aflatoxins risks in China is a vaccination against hepatitis $B$. This vaccination plays an important role in the reduction and prevention of cancer that might be caused by dietary exposure to aflatoxins in China (Chen et al., 2013).

Photocatalytic degradation is a recently developed technique to remove and/or degrade pollutants, including aflatoxins, from environment in gentle or mild conditions (Bai et al., 2017; Sun et al., 2019; Wang et al., 2019a). A recent study, Mao et al. (2018a) revealed that the nanosized graphitic carbon nitride sheets $\left(\mathrm{g}-\mathrm{C}_{3} \mathrm{~N}_{4}\right)$ presents a significantly higher photocatalytic activity for degradation of $\mathrm{AFB}_{1}$ in aqueous solutions. The enhanced photocatalytic mechanisms were a result of better photogenerated charges separation and larger surface area of nanosized $g-\mathrm{C}_{3} \mathrm{~N}_{4}$ sheets. Although this technique provided good results, a later study (Mao et al., 2018b) suggested that it was a good idea to explore more convenient and expedient strategies to improve the performance of pristine $g-\mathrm{C}_{3} \mathrm{~N}_{4}$. To this end, they designed a geometric architecture of ternary Z-scheme composites consisting of bulk g- $\mathrm{C}_{3} \mathrm{~N}_{4}, \mathrm{WO}_{3}$ nanowires and $\mathrm{RGO}\left(\mathrm{WO}_{3} / \mathrm{RGO} / \mathrm{g}-\mathrm{C}_{3} \mathrm{~N}_{4}\right)$ for enhanced visible-light-driven activity of refractory $\mathrm{AFB}_{1}$ degradation. Their results indicate that the use of the above-mentioned composites as an electron mediator could markedly increase the photocatalytic activity of pristine $g-\mathrm{C}_{3} \mathrm{~N}_{4}$ for $\mathrm{AFB}_{1}$ degradation under visible-light irradiation (Mao et al., 2018b). In a similar fashion, a kind of all-solid-state Z-scheme composite obtained by depositing $\mathrm{CdS}$ on the surface of clew-like $\mathrm{WO}_{3}$ was able to sharply reduce the toxicity of $\mathrm{AFB}_{1}$ in aqueous solution under visible light radiation (Mao et al., 2019).

In summary, all the above-mentioned control and prevention strategies can greatly help in reducing diseases caused by aflatoxins. These control and prevention strategies would equally increase both positive economic impact for farmers and the production of seed crops.

\section{Conclusions and future outlook of aflatoxins in China}

The current level of research relating to the incidence of aflatoxins in human, animals and foodstuff in Asian countries have demonstrated the seriousness of the aflatoxin problem these days. In China, the topographic complexity and extensiveness, as well as the distinctly different climate zones have provided diverse favourable environmental conditions for the growth of aflatoxin-producing fungi.
Generally, the level of aflatoxin contamination detected in the southern area of China is greater than that in the northern part. However, the diminution of aflatoxins risk could rely on the feed and food safety management by the production companies and government. In recent years, Chinese feed and food companies have tried to improve their standardised running protocols for aflatoxin control/ management, which has made China to be classified among the countries in Asia that have the most detailed and extensive process of regulation for mycotoxins including aflatoxins (Van Egmond and Jonker, 2004). The Chinese government has equally been improving these regulations to avoid these toxins reach consumers all over the country. Also, the management and supervision of production, consumption and distribution chains by the liable agencies have been gradually improved.

Although the Chinese government has established some regulations and laws in response to aflatoxin contamination, additional efforts are still needed to minimise the aflatoxin levels in food and their risks to the human and animal health in the country. Therefore, the future outlook with regard to aflatoxin prevention in China can be anticipated. Firstly, the stakeholders in the manufacturing chain, especially farmers, should be made conscious of the value of measures to decrease aflatoxin contamination to guarantee their safety and protect consumers. Secondly, people at all levels, such as technicians, scientists and extension agents should be trained timely and rightly. Thirdly, we should use the most accurate techniques to detect aflatoxins that are recently documented. Fourthly, we should carry out periodically and extensively surveys about the incidence of aflatoxins and their metabolites in human's breast milk, since severe health risks to the infant, foetus, and mother can occur.

\section{Acknowledgements}

This work was supported by National Natural Science Foundation of China (No. 31772105) and Natural Science Foundation of Fujian Province of China (No. 2018J07002).

\section{Conflict of interest}

The authors declare no conflict of interest.

\section{References}

Agrios, G., 2005. Plant pathology, $5^{\text {th }}$ edition. Elsevier Academic Press, New York, NY, USA.

Ahmad, S., Wang, S., Wu, W., Yang, K., Zhang, Y., Tumukunde, E., Wang, S. and Wang, Y., 2019. Functional analysis of peptidyl-prolyl cis-trans isomerase from Aspergillus flavus. International Journal of Molecular Sciences 20: 2206. 
Al-Gabr, H.M., Ye, C., Zhang, Y., Khan, S., Lin, H. and Zheng, T., 2013. Effects of carbon, nitrogen and $\mathrm{pH}$ on the growth of Aspergillus parasiticus and aflatoxins production in water. Journal of Environmental Biology 34: 353.

Al-Gabr, H.M., Zheng, T. and Yu, X., 2014. Occurrence and quantification of fungi and detection of mycotoxigenic fungi in drinking water in Xiamen City, China. Science of the Total Environment 466: 1103-1111.

Al-Tamimi, N., 2017. The rise of China: Beijing's core interests and possible Arab repercussions. Contemporary Arab Affairs 10: 596-622.

Amaike, S. and Keller, N.P., 2011. Aspergillus flavus. Annual Review of Phytopathology 49: 107-133.

Andersen, N., St F, B., Harris, C., Harris, T.M., Hecker, E., Hindley, K., McGregor, D., Marshall, J., Roberts, J. and Schmidt, R., 2012. Fortschritte der Chemie Organischer Naturstoffe/Progress in the chemistry of organic natural products, 31 . Springer Science \& Business Media, Cham, Switzerland.

Bai, X., Sun, C., Liu, D., Luo, X., Li, D., Wang, J., Wang, N., Chang, X., Zong, R. and Zhu, Y., 2017. Photocatalytic degradation of deoxynivalenol using graphene/ZnO hybrids in aqueous suspension. Applied Catalysis B 204: 11-20.

Bakırdere, S., Bora, S., Bakırdere, E.G. Aydın, F., Arslan, Y., Komesli, O.T., Aydın, I. and Yıldırım, E., 2012. Aflatoxin species: their health effects and determination methods in different foodstuffs. Central European Journal of Chemistry 10: 675-685.

Barrett, J.R., 2005. Liver cancer and aflatoxin: new information from the Kenyan outbreak. Environmental Health Perspectives 113: A837-A838.

Beltrán, E., Ibáñez, M., Sancho, J.V., Cortés, M.Á., Yusà, V. and Hernández, F., 2011. UHPLC-MS/MS highly sensitive determination of aflatoxins, the aflatoxin metabolite $\mathrm{M}_{1}$ and ochratoxin $\mathrm{A}$ in baby food and milk. Food Chemistry 126: 737-744.

Bianco, G., Russo, R., Marzocco, S., Velotto, S., Autore, G. and Severino, L., 2012. Modulation of macrophage activity by aflatoxins $B_{1}$ and $B_{2}$ and their metabolites aflatoxins $M_{1}$ and $M_{2}$. Toxicon 59: 644-650.

Cardwell, K.F. and Henry, S.H., 2004. Risk of exposure to and mitigation of effect of aflatoxin on human health: a West African example. Journal of Toxicology: Toxin Reviews 23: 217-247.

Cary, J., Klich, M. and Beltz, S., 2005. Characterization of aflatoxinproducing fungi outside of Aspergillus section Flavi. Mycologia 97: 425-432.

Central Intelligence Agency (CIA), 2019. The World Factbook: China. Available at: https://www.cia.gov/library/publications/the-worldfactbook/geos/ch.html

Chen, J.-G., Egner, P.A., Ng, D., Jacobson, L.P., Muñoz, A., Zhu, Y.-R., Qian, G.-S., Wu, F., Yuan, J.-M. and Groopman, J.D., 2013. Reduced aflatoxin exposure presages decline in liver cancer mortality in an endemic region of China. Cancer Prevention Research 6: 1038-1045.

Chen, X., Horn, N. and Applegate, T., 2014. Efficiency of hydrated sodium calcium aluminosilicate to ameliorate the adverse effects of graded levels of aflatoxin $B_{1}$ in broiler chicks. Poultry Science 93: 2037-2047.
Chen, X., Wang, H., Xie, W., Liang, R., Wei, Z., Zhi, L., Zhang, X., Hao, B., Zhong, S. and Zhou, G., 2006. Association of CYP1A2 genetic polymorphisms with hepatocellular carcinoma susceptibility: a case-control study in a high-risk region of China. Pharmacogenetics and Genomics 16: 219-227.

Choudhary, A.K. and Kumari, P., 2010. Management of mycotoxin contamination in preharvest and post-harvest crops: present status and future prospects. Journal of Phytology 2: 37-52.

Cole, R.J., Schweikert, M.A. and Jarvis, B.B., 2003. Handbook of secondary fungal metabolites, 3-volume set. Elsevier, New York, NY, USA.

De Iongh, H., Vles, R. and de Vogel, P., 1964. The occurrence and detection of aflatoxin in food. In: Wogan, G.H. (ed.) Proceedings of the symposium on mycotoxins in foodstuffs. MIT Press, Cambridge, MA, USA, p. 235

Dhanasekaran, D., Shanmugapriya, S., Thajuddin, N. and Panneerselvam, A., 2011. Aflatoxins and aflatoxicosis in human and animals. Aflatoxins - biochemistry and molecular biology. IntechOpen, London, UK.

Diao, E., Dong, H., Hou, H., Zhang, Z., Ji, N. and Ma, W., 2015. Factors influencing aflatoxin contamination in before and after harvest peanuts: a review. Journal of Food Research 4: 148.

Ding, X., Li, P., Bai, Y. and Zhou, H., 2012. Aflatoxin $B_{1}$ in post-harvest peanuts and dietary risk in China. Food Control 23: 143-148.

Ding, X., Wu, L., Li, P., Zhang, Z., Zhou, H., Bai, Y., Chen, X. and Jiang, J., 2015. Risk assessment on dietary exposure to aflatoxin $B_{1}$ in post-harvest peanuts in the Yangtze River ecological region. Toxins 7: 4157-4174.

Dwivedi, S., Sahrawat, K., Upadhyaya, H. and Ortiz, R., 2013. Food, nutrition and agrobiodiversity under global climate change. In: Spark, D. (ed.) Advances in agronomy. Elsevier, New York, NY, USA, pp. 1-128.

Egner, P.A., Wang, J.-B., Zhu, Y.-R., Zhang, B.-C., Wu, Y., Zhang, Q.N., Qian, G.-S., Kuang, S.-Y., Gange, S.J. and Jacobson, L.P., 2001. Chlorophyllin intervention reduces aflatoxin-DNA adducts in individuals at high risk for liver cancer. Proceedings of the National Academy of Sciences of the USA 98: 14601-14606.

Evtugyn, G. and Hianik, T., 2019. Electrochemical immuno-and aptasensors for mycotoxin determination. Chemosensors 7: 10.

Fahey, J.W., Stephenson, K.K., Dinkova-Kostova, A.T., Egner, P.A., Kensler, T.W. and Talalay, P., 2005. Chlorophyll, chlorophyllin and related tetrapyrroles are significant inducers of mammalian phase 2 cytoprotective genes. Carcinogenesis 26: 1247-1255.

Fallah, A.A., Rahnama, M., Jafari, T. and Saei-Dehkordi, S.S., 2011. Seasonal variation of aflatoxin $\mathrm{M}_{1}$ contamination in industrial and traditional Iranian dairy products. Food Control 22: 1653-1656.

Fan, Y., Li, X.-y., Zhao, L.-h., Jia, Y.-x., Ji, C., Ma, Q.-g., Chen, Y. and Wang, L., 2012. Investigation on contamination situation of aflatoxin in detected feeds and feedstuffs in Beijing area. Scientia Agricultura Sinica 45: 5102-5109.

Farombi, O.E., 2006. Aflatoxin contamination of foods in developing countries: Implications for hepatocellular carcinoma and chemopreventive strategies. African Journal of Biotechnology 5: $1-14$. 
Fouad, A.M., Ruan, D., El-Senousey, H.K., Chen, W., Jiang, S. and Zheng, C., 2019. Harmful effects and control strategies of aflatoxin $\mathrm{B}_{1}$ produced by Aspergillus flavus and Aspergillus parasiticus strains on poultry. Toxins 11: 176.

$\mathrm{Fu}$, C.Y., 2014. The method to detect three mycotoxins in maize. MSc-thesis, Shandong Agricultural University, Tai'an, China P.R.

Gao, J., Liu, Z. and Yu, J., 2007. Identification of Aspergillus section Flavi in maize in northeastern China. Mycopathologia 164: 91-95.

Gao, X.-f., Yin, S.-a., Zhang, H.-y., Han, C., Zhao, X. and Ji, R., 2011. Aflatoxin contamination of corn samples collected from six regions of China. Journal of Hygiene Research 40: 46-49.

Ghali, R., Belouaer, I., Hdiri, S., Ghorbel, H., Maaroufi, K. and Hedilli, A., 2009. Simultaneous HPLC determination of aflatoxins $B_{1}, B_{2}$, $G_{1}$ and $G_{2}$ in Tunisian sorghum and pistachios. Journal of Food Composition and Analysis 22: 751-755.

Goldblatt, L., 2012. Aflatoxin: scientific background, control, and implications. Elsevier, New York, NY, USA.

Gonçalves, S.S., Cano, J.F., Stchigel, A.M., Melo, A.S., Godoy-Martinez, P.C., Correa, B. and Guarro, J., 2012. Molecular phylogeny and phenotypic variability of clinical and environmental strains of Aspergillus flavus. Fungal Biology 116: 1146-1155.

Gong, A., WH, L. and JJ, D., 2016. Analysis of mycotoxins contamination of maize on national markets in 2015. China Feed 4: 42-44.

Gong, Y., Li, F. and Routledge, M.N., 2017. Mycotoxins in China: occurrence and exposure. In: Jen, J.J. and Chen, J. (eds.) Food safety in China: science, technology, management and regulation. John Wiley \& Sons Ltd., Hoboken, NJ, USA, pp. 83-101.

Goss, P.E., Strasser-Weippl, K., Lee-Bychkovsky, B.L., Fan, L., Li, J., Chavarri-Guerra, Y., Liedke, P.E., Pramesh, C., Badovinac-Crnjevic, T. and Sheikine, Y., 2014. Challenges to effective cancer control in China, India, and Russia. The Lancet Oncology 15: 489-538.

Gratz, S., Mykkänen, H. and El-Nezami, H., 2005. Aflatoxin B binding by a mixture of Lactobacillus and Propionibacterium: in vitro versus ex vivo. Journal of Food Protection 68: 2470-2474.

Guan, S., Gong, M., Yin, Y., Huang, R., Ruan, Z., Zhou, T. and Xie, M., 2011a. Occurrence of mycotoxins in feeds and feed ingredients in China. Journal of Food, Agriculture and Environment 9: 163-167.

Guan, S., Zhou, T., Yin, Y., Xie, M., Ruan, Z. and Young, J., $2011 \mathrm{~b}$. Microbial strategies to control aflatoxins in food and feed. World Mycotoxin Journal 4: 413-424.

Guo, B., Yu, J., Holbrook, C.C., Cleveland, T.E., Nierman, W.C. and Scully, B.T., 2009. Strategies in prevention of preharvest aflatoxin contamination in peanuts: aflatoxin biosynthesis, genetics and genomics. Peanut Science 36: 11-20.

Guo, Y., Yuan, Y. and Yue, T., 2013. Aflatoxin $\mathrm{M}_{1}$ in milk products in China and dietary risk assessment. Journal of Food Protection 76: 849-853.

Guzmán-de-Peña, D. and Peña-Cabriales, J.J., 2005. Regulatory considerations of aflatoxin contamination of food in Mexico. Revista Latinoamericana de Microbiología 47: 160-164.

Hamid, A.S., Tesfamariam, I.G., Zhang, Y. and Zhang, Z.G., 2013. Aflatoxin $\mathrm{B}_{1}$-induced hepatocellular carcinoma in developing countries: geographical distribution, mechanism of action and prevention. Oncology Letters 5: 1087-1092.
Han, Z., Zheng, Y., Luan, L., Cai, Z., Ren, Y. and Wu, Y., 2010. An ultra-high-performance liquid chromatography-tandem mass spectrometry method for simultaneous determination of aflatoxins $B_{1}, B_{2}, G_{1}, G_{2}, M_{1}$ and $M_{2}$ in traditional Chinese medicines. Analytica Chimica Acta 664: 165-171.

Hedayati, M., Pasqualotto, A., Warn, P., Bowyer, P. and Denning, D., 2007. Aspergillus flavus: human pathogen, allergen and mycotoxin producer. Microbiology 153: 1677-1692.

Heidtmann-Bemvenuti, R., Mendes, G., Scaglioni, P., Badiale-Furlong, E. and Souza-Soares, L., 2011. Biochemistry and metabolism of mycotoxins: a review. African Journal of Food Science 5: 861-869.

Hell, K., Fandohan, P., Bandyopadhyay, R., Kiewnick, S., Sikora, R. and Cotty, P.J., 2008. Pre-and post-harvest management of aflatoxin in maize: an African perspective. In: Leslie, J., Bandyopadhyay, R. and Visconti, A. (eds.) Mycotoxins: detection methods, management, public health and agricultural trade. CAB International, Wallingford, UK, pp. 219-229.

Hell, K., Mutegi, C. and Fandohan, P., 2010. Aflatoxin control and prevention strategies in maize for sub-Saharan Africa. Julius-KühnArchiv 425: 534-541.

Herzallah, S.M., 2009. Determination of aflatoxins in eggs, milk, meat and meat products using HPLC fluorescent and UV detectors. Food Chemistry 114: 1141-1146.

Holzapfel, C., Steyn, P. and Purchase, I., 1966. Isolation and structure of aflatoxins $M_{1}$ and $M_{2}$. Tetrahedron Letters 7: 2799-2803.

International Agency for Research on Cancer (IARC), 2002. Aflatoxins. In: Monograph on the evaluation of carcinogenic risks to humans. Vol. 82. Some traditional herbal medicines, some mycotoxins, naphthalene and styrene. IARC, Lyon, France, pp. 171-300.

Ip, S.-P. and Che, C.-T., 2006. Determination of aflatoxins in Chinese medicinal herbs by high-performance liquid chromatography using immunoaffinity column cleanup: improvement of recovery. Journal of Chromatography A 1135: 241-244.

Iqbal, S., Asi, M. and Ariño, A., 2017. Aflatoxins, reference module in life sciences. Elsevier, New York, NY, USA.

Jaimez, J., Fente, C., Vazquez, B., Franco, C., Cepeda, A., Mahuzier, G. and Prognon, P., 2000. Application of the assay of aflatoxins by liquid chromatography with fluorescence detection in food analysis. Journal of Chromatography A 882: 1-10.

Juan, C., Zinedine, A., Molto, J., Idrissi, L. and Manes, J., 2008. Aflatoxins levels in dried fruits and nuts from Rabat-Salé area, Morocco. Food Control 19: 849-853.

Kew, M.C., 2013. Aflatoxins as a cause of hepatocellular carcinoma. Journal of Gastrointestinal and Liver Diseases 22: 305-310.

Khlangwiset, P., Shephard, G.S. and Wu, F., 2011. Aflatoxins and growth impairment: a review. Critical Reviews in Toxicology 41: 740-755.

Krska, R., Schubert-Ullrich, P., Molinelli, A., Sulyok, M., MacDonald, S. and Crews, C., 2008. Mycotoxin analysis: an update. Food Additives and Contaminants Part A 25: 152-163.

Kumar, V.V., 2018. Aflatoxins: properties, toxicity and detoxification. Nutrition and Food Science 6: 555696. https://doi.org/10.19080/ NFSIJ.2018.06.555696

Lai, X., Liu, R., Ruan, C., Zhang, H. and Liu, C., 2015a. Occurrence of aflatoxins and ochratoxin $\mathrm{A}$ in rice samples from six provinces in China. Food Control 50: 401-404. 
Lai, X., Zhang, H., Liu, R. and Liu, C., 2015b. Potential for aflatoxin $B_{1}$ and $\mathrm{B}_{2}$ production by Aspergillus flavus strains isolated from rice samples. Saudi Journal of Biological Sciences 22: 176-180.

Lan, H., Wu, L., Fan, K., Sun, R., Yang, G., Zhang, F., Yang, K., Lin, X., Chen, Y. and Tian, J., 2019. Set3 is required for asexual development, aflatoxin biosynthesis and fungal virulence in Aspergillus flavus. Frontiers in Microbiology 10: 530.

Ledoux, D., Rottinghaus, G., Bermudez, A. and Alonso-Debolt, M., 1999. Efficacy of a hydrated sodium calcium aluminosilicate to ameliorate the toxic effects of aflatoxin in broiler chicks. Poultry Science 78: 204-210.

Li, F.-Q., Li, Y.-W., Wang, Y.-R. and Luo, X.-Y., 2009a. Natural occurrence of aflatoxins in Chinese peanut butter and sesame paste. Journal of Agricultural and Food Chemistry 57: 3519-3524.

Li, F.-Q., Yoshizawa, T., Kawamura, O., Luo, X.-Y. and Li, Y.-W., 2001. Aflatoxins and fumonisins in corn from the high-incidence area for human hepatocellular carcinoma in Guangxi, China. Journal of Agricultural and Food Chemistry 49: 4122-4126.

Li, H., Xing, L., Zhang, M., Wang, J. and Zheng, N., 2018. The toxic effects of aflatoxin $B_{1}$ and aflatoxin $M_{1}$ on kidney through regulating $\mathrm{L}$-proline and downstream apoptosis. BioMed Research International 2018: 9074861.

Li, P., Zhang, Q., Zhang, W., Zhang, J., Chen, X., Jiang, J., Xie, L. and Zhang, D., 2009b. Development of a class-specific monoclonal antibody-based ELISA for aflatoxins in peanut. Food Chemistry 115: 313-317.

Li, R., Wang, X., Zhou, T., Yang, D., Wang, Q. and Zhou, Y., 2014. Occurrence of four mycotoxins in cereal and oil products in Yangtze Delta region of China and their food safety risks. Food Control 35: 117-122.

Liao, B., Zhuang, W., Tang, R., Zhang, X., Shan, S., Jiang, H. and Huang, J., 2009. Peanut aflatoxin and genomics research in China: progress and perspectives. Peanut Science 36: 21-28.

Lin, G., Fu, J., Jiang, D., Wang, J., Wang, Q. and Dong, D., 2015. Spatial variation of the relationship between PM2. 5 concentrations and meteorological parameters in China. BioMed Research International 2015, Article ID: 684618.

Linting, Z., Ruiyi, L., Zaijun, L., Qianfang, X., Yinjun, F. and Junkang, L., 2012. An immunosensor for ultrasensitive detection of aflatoxin $B_{1}$ with an enhanced electrochemical performance based on graphene/ conducting polymer/gold nanoparticles/the ionic liquid composite film on modified gold electrode with electrodeposition. Sensors and Actuators B: Chemical 174: 359-365.

Liu, J. and Diamond, J., 2005. China's environment in a globalizing world. Nature 435: 1179 .

Liu, J., Sun, L., Zhang, N., Zhang, J., Guo, J., Li, C., Rajput, S.A. and Qi, D., 2016. Effects of nutrients in substrates of different grains on aflatoxin $\mathrm{B}_{1}$ production by Aspergillus flavus. BioMed Research International 2016: 7232858.

Liu, S., Qiu, F., Kong, W., Wei, J., Xiao, X. and Yang, M., 2013. Development and validation of an accurate and rapid LC-ESI-MS/ MS method for the simultaneous quantification of aflatoxin $B_{1}, B_{2}$, $\mathrm{G}_{1}$ and $\mathrm{G}_{2}$ in lotus seeds. Food Control 29: 156-161.
Liu, X., Guan, X., Xing, F., Lv, C., Dai, X. and Liu, Y., 2017. Effect of water activity and temperature on the growth of Aspergillus flavus, the expression of aflatoxin biosynthetic genes and aflatoxin production in shelled peanuts. Food Control 82: 325-332.

Liu, Y. and Wu, F., 2010. Global burden of aflatoxin-induced hepatocellular carcinoma: a risk assessment. Environmental Health Perspectives 118: 818-824.

Liu, Y., Qin, Z., Wu, X. and Jiang, H., 2006a. Immune-biosensor for aflatoxin $\mathrm{B}_{1}$ based bio-electrocatalytic reaction on micro-comb electrode. Biochemical Engineering Journal 32: 211-217.

Liu, Y., Yang, L., Yang, N., Dong, B., Cao, L., Wang, K. and Yang, L., 2012. Occurrence of fumonisins and aflatoxins in cereals from markets of Hebei province of China. Food Additives and Contaminants Part B 5: 208-211.

Liu, Z., Gao, J. and Yu, J., 2006b. Aflatoxins in stored maize and rice grains in Liaoning Province, China. Journal of Stored Products Research 42: 468-479.

Lu, Z., Wu, S. and Sun, C., 2010. The relationship of aflatoxin biosynthetic gene expression and environmental factors. Biotechnology Bulletin 11: 56-61.

Ma, H., Zhang, N., Sun, L. and Qi, D., 2015. Effects of different substrates and oils on aflatoxin $\mathrm{B}_{1}$ production by Aspergillus parasiticus. European Food Research and Technology 240: 627-634.

Ma, J.J., Shao, B., Lin, X.H., Yu, H.X. and Li, F.Q., 2011. Study on the natural occurrence of multi-mycotoxin in cereal and cereal-based product samples collected from parts of China in 2010. Chinese Journal of Food Hygiene 23: 481-488.

Ma, X., Wang, W., Chen, X., Xia, Y., Wu, S., Duan, N. and Wang, Z., 2014. Selection, identification, and application of aflatoxin $B_{1}$ aptamer. European Food Research and Technology 238: 919-925.

Mao, J., Li, P., Wang, J., Wang, H., Zhang, Q., Zhang, L., Li, H., Zhang, W. and Peng, T., 2019. Insights into photocatalytic inactivation mechanism of the hypertoxic site in aflatoxin $\mathrm{B}_{1}$ over clew-like WO3 decorated with CdS nanoparticles. Applied Catalysis B 248: 477-486.

Mao, J., Zhang, L., Wang, H., Zhang, Q., Zhang, W. and Li, P., 2018a. Facile fabrication of nanosized graphitic carbon nitride sheets with efficient charge separation for mitigation of toxic pollutant. Chemical Engineering Journal 342: 30-40.

Mao, J., Zhang, Q., Li, P., Zhang, L. and Zhang, W., 2018b. Geometric architecture design of ternary composites based on dispersive WO3 nanowires for enhanced visible-light-driven activity of refractory pollutant degradation. Chemical Engineering Journal 334: 25682578.

McGlynn, K.A. and London, W.T., 2005. Epidemiology and natural history of hepatocellular carcinoma. Best Practice and Research Clinical Gastroenterology 19: 3-23.

Monson, M.S., Settlage, R.E., McMahon, K.W., Mendoza, K.M., Rawal, S., El-Nezami, H.S., Coulombe, R.A. and Reed, K.M., 2014. Response of the hepatic transcriptome to aflatoxin $\mathrm{B}_{1}$ in domestic turkey (Meleagris gallopavo). PLoS ONE 9: e100930.

Moss, M.O., 2002. Risk assessment for aflatoxins in foodstuffs. International Biodeterioration and Biodegradation 50: 137-142.

Motawee, M. and McMahon, D.J., 2009. Fate of aflatoxin $M_{1}$ during manufacture and storage of feta cheese. Journal of Food Science 74: T42-T45. 
Mwakinyali, S.E., Ming, Z., Xie, H., Zhang, Q. and Li, P., 2019. Investigation and characterization of Myroides odoratimimus strain 3J2MO aflatoxin $\mathrm{B}_{1}$ degradation. Journal of Agricultural and Food Chemistry 67: 4595-4602.

Mzungu, I., Hamisu, H. and Umar, K., 2018. Evaluation of moulds contamination of cereals and legumes sold in Dutsinma metropolis and their aflatoxin production potential. FUDMA Journal of Sciences 2: 94-98.

Negash, D., 2018. A review of aflatoxin: occurrence, prevention, and gaps in both food and feed safety. Journal of Applied Microbiological Research 1: 35-43.

OBrian, G., Georgianna, D., Wilkinson, J., Yu, J., Abbas, H., Bhatnagar, D., Cleveland, T., Nierman, W. and Payne, G., 2007. The effect of elevated temperature on gene transcription and aflatoxin biosynthesis. Mycologia 99: 232-239.

O’Neil, M., Smith, A., Heckelman, P. and Budavari, S., 2001. The Merck index - an encyclopedia of chemicals, drugs, and biologicals. Merck and Co. Inc., Whitehouse Station, NJ, USA.

Palmisano, F., Zambonin, P.G., Visconti, A. and Bottalico, A., 1989. Profiling of Alternaria mycotoxins in foodstuffs by high-performance liquid chromatography with diode-array ultraviolet detection. Journal of Chromatography 465: 305-313.

Pei, S.C., Zhang, Y.Y., Eremin, S.A. and Lee, W.J., 2009. Detection of aflatoxin M1 in milk products from China by ELISA using monoclonal antibodies. Food Control 20: 1080-1085.

Prandini, A., Tansini, G., Sigolo, S., Filippi, L., Laporta, M. and Piva, G., 2009. On the occurrence of aflatoxin M1 in milk and dairy products. Food and Chemical Toxicology 47: 984-991.

Qian, G.-S., Ross, R.K., Yu, M.C., Yuan, J.-M., Gao, Y.-T., Henderson, B.E., Wogan, G.N. and Groopman, J.D., 1994. A follow-up study of urinary markers of aflatoxin exposure and liver cancer risk in Shanghai, People's Republic of China. Cancer Epidemiology and Prevention Biomarkers 3: 3-10.

Rawal, S., Kim, J.E. and Coulombe Jr., R., 2010. Aflatoxin $B_{1}$ in poultry: toxicology, metabolism and prevention. Research in Veterinary Science 89: 325-331.

Ren, S., Yang, M., Yue, Y., Ge, F., Li, Y., Guo, X., Zhang, J., Zhang, F., Nie, X. and Wang, S., 2018. Lysine succinylation contributes to aflatoxin production and pathogenicity in Aspergillus flavus. Molecular and Cellular Proteomics 17: 457-471.

Royes, J. and Yanong, R., 2002. Molds in fish feeds and aflatoxicosis. University of Florida, Institute of Agriculture Science, Gainesville, FL, USA.

Santos Pereira, C., C Cunha, S. and Fernandes, J.O., 2019. Prevalent mycotoxins in animal feed: occurrence and analytical methods. Toxins 11: 290.

Schmidt-Heydt, M., Rüfer, C.E., Abdel-Hadi, A., Magan, N. and Geisen, R., 2010. The production of aflatoxin $B_{1}$ or $G_{1}$ by Aspergillus parasiticus at various combinations of temperature and water activity is related to the ratio of aflS to aflR expression. Mycotoxin Research 26: 241-246.

Set, E. and Erkmen, O., 2010. The aflatoxin contamination of ground red pepper and pistachio nuts sold in Turkey. Food and Chemical Toxicology 48: 2532-2537.
Shim, W., Yang, Z., Kim, J., Kim, J., Kang, S., Woo, G., Chung, Y., Eremin, S.A. and Chung, D., 2007. Development of immunochromatography strip-test using nanocolloidal gold-antibody probe for the rapid detection of aflatoxin $B_{1}$ in grain and feed samples. Journal of Microbiology and Biotechnology 17: 1629.

Shu, X., Wang, Y., Zhou, Q., Li, M., Hu, H., Ma, Y., Chen, X., Ni, J., Zhao, W. and Huang, S., 2018. Biological degradation of aflatoxin $\mathrm{B}_{1}$ by cell-free extracts of Bacillus velezensis DY3108 with broad PH stability and excellent thermostability. Toxins 10: 330 .

Stadler, S., 2015. NCGE member travels: a visit to China. The Geography Teacher 12: 85-94.

Stroka, J., Van Otterdijk, R. and Anklam, E., 2000. Immunoaffinity column clean-up prior to thin-layer chromatography for the determination of aflatoxins in various food matrices. Journal of Chromatography A 904: 251-256.

Stubblefield, R., Shotwell, O. and Shannon, G., 1972. Aflatoxins $M_{1}$ and $\mathrm{M}_{2}$ and parasiticol: thin layer chromatography and physical and chemical properties. Journal of the Association of Official Analytical Chemists 55: 762-767.

Su, C., Hu, Y., Gao, D., Luo, Y., Chen, A.J., Jiao, X. and Gao, W., 2018. Occurrence of toxigenic fungi and mycotoxins on root herbs from Chinese markets. Journal of Food Protection 81: 754-761.

Sun, D.-D., Gu, X., Li, J.-G., Yao, T. and Dong, Y.-C., 2015. Quality evaluation of five commercial enzyme linked immunosorbent assay kits for detecting aflatoxin $B_{1}$ in feedstuffs. Asian-Australasian Journal of Animal Sciences 28: 691.

Sun, G., Wang, S., Hu, X., Su, J., Zhang, Y., Xie, Y., Zhang, H., Tang, L. and Wang, J.-S., 2011. Co-contamination of aflatoxin $B_{1}$ and fumonisin $B_{1}$ in food and human dietary exposure in three areas of China. Food Additives and Contaminants Part A 28: 461-470.

Sun, S., Zhao, R., Xie, Y. and Liu, Y., 2019. Photocatalytic degradation of aflatoxin $\mathrm{B}_{1}$ by activated carbon supported $\mathrm{TiO}_{2}$ catalyst. Food Control 100: 183-188.

Sun, X.D., Su, P. and Shan, H., 2017. Mycotoxin contamination of rice in China. Journal of Food Science 82: 573-584.

Sun, Z., Chen, T., Thorgeirsson, S.S., Zhan, Q., Chen, J., Park, J.-H., Lu, P., Hsia, C.C., Wang, N. and Xu, L., 2013. Dramatic reduction of liver cancer incidence in young adults: 28-year follow-up of etiological interventions in an endemic area of China. Carcinogenesis 34: 1800-1805.

Tominaga, M., Lee, Y.-H., Hayashi, R., Suzuki, Y., Yamada, O., Sakamoto, K., Gotoh, K. and Akita, O., 2006. Molecular analysis of an inactive aflatoxin biosynthesis gene cluster in Aspergillus oryzae RIB strains. Applied and Environmental Microbiology 72: 484-490.

Tumukunde, E., Li, D., Qin, L., Li, Y., Shen, J., Wang, S. and Yuan, J., 2019. Osmotic-adaptation response of sakA/hogA gene to aflatoxin biosynthesis, morphology development and pathogenicity in Aspergillus flavus. Toxins 11: 41.

Turner, N.W., Subrahmanyam, S. and Piletsky, S.A., 2009. Analytical methods for determination of mycotoxins: a review. Analytica Chimica Acta 632: 168-180.

Van Egmond, H.P. and Jonker, M., 2004. Worldwide regulations for mycotoxins in food and feed in 2003. FAO Food and Nutrition Paper 81, Rome, Italy. 
Ventura, M., Gómez, A., Anaya, I., Díaz, J., Broto, F., Agut, M. and Comellas, L., 2004. Determination of aflatoxins $B_{1}, G_{1}, B_{2}$ and $\mathrm{G}_{2}$ in medicinal herbs by liquid chromatography-tandem mass spectrometry. Journal of Chromatography A 1048: 25-29.

Versantvoort, C.H., Oomen, A.G., Van de Kamp, E., Rompelberg, C.J. and Sips, A.J., 2005. Applicability of an in vitro digestion model in assessing the bioaccessibility of mycotoxins from food. Food and Chemical Toxicology 43: 31-40.

Viegas, S., Veiga, L., Figueredo, P., Almeida, A., Carolino, E., Sabino, R., Veríssimo, C. and Viegas, C., 2013. Occupational exposure to aflatoxin $B_{1}$ in swine production and possible contamination sources. Journal of Toxicology and Environmental Health Part A 76: 944-951.

Wacoo, A.P., Wendiro, D., Vuzi, P.C. and Hawumba, J.F., 2014. Methods for detection of aflatoxins in agricultural food crops. Journal of Applied Chemistry 2014: 706291.

Wang, H., Mao, J., Zhang, Z., Zhang, Q., Zhang, L. and Li, P., 2019a. Photocatalytic degradation of deoxynivalenol over dendritic-like $\alpha-\mathrm{Fe}_{2} \mathrm{O}_{3}$ under visible light irradiation. Toxins 11: 105.

Wang, J. and Liu, X., 2007a. Assessment of dietary aflatoxins exposure in Chinese residents. Chinese Journal of Food Hygiene 3: 238-240.

Wang, J. and Liu, X., 2007b. Contamination of aflatoxins in different kinds of foods in China. Biomedical and Environmental Sciences 20: 483-487.

Wang, J., Liu, X. and Zhang, Z., 2009. Exposure assessment of liver cancer attributed to dietary aflatoxins exposure in Chinese residents. Chinese Journal of Preventive Medicine 43: 478-481.

Wang, J.-J., Liu, B.-H., Hsu, Y.-T. and Yu, F.-Y., 2011. Sensitive competitive direct enzyme-linked immunosorbent assay and gold nanoparticle immunochromatographic strip for detecting aflatoxin M1 in milk. Food Control 22: 964-969.

Wang, J.-S., Huang, T., Su, J., Liang, F., Wei, Z., Liang, Y., Luo, H., Kuang, S.-Y., Qian, G.-S. and Sun, G., 2001. Hepatocellular carcinoma and aflatoxin exposure in Zhuqing village, Fusui county, People's Republic of China. Cancer Epidemiology and Prevention Biomarkers 10: 143-146.

Wang, L., Wu, J., Liu, Z., Shi, Y., Liu, J., Xu, X., Hao, S., Mu, P., Deng, F. and Deng, Y., 2018. Aflatoxin B1 degradation and detoxification by Escherichia coli CG1061 isolated from chicken cecum. Frontiers in Pharmacology 9: 1548.

Wang, M.-Q., Wang, Z., Yu, L.-N., Zhang, C.-S., Bi, J. and Sun, J., 2019b. Pseudomonas qingdaonensis sp. nov., an aflatoxin-degrading bacterium, isolated from peanut rhizospheric soil. Archives of Microbiology 201: 673-678.

Wang, T., Li, C., Liu, Y., Li, T., Zhang, J. and Sun, Y., 2015. Inhibition effects of Chinese cabbage powder on aflatoxin $\mathrm{B}_{1}$-induced liver cancer. Food Chemistry 186: 13-19.

Wang, T., Li, P., Zhang, Q., Zhang, W., Zhang, Z., Wang, T. and He, T., 2017. Determination of Aspergillus pathogens in agricultural products by a specific nanobody-polyclonal antibody sandwich ELISA. Scientific Reports 7: 4348.

Wang, X., 2015. Magnetic bead-based immunoassays for aflatoxin $B_{1}$ using biofunctionalized gold nanoparticles. Technische Universität München, München, Germany.

Wannop, C., 1961. The histopathology of turkey' X' disease in Great Britain. Avian Diseases 5: 371-381.
Wild, C. and Turner, P., 2002. The toxicology of aflatoxins as a basis for public health decisions. Mutagenesis 17: 471-481.

Williams, J.H., Phillips, T.D., Jolly, P.E., Stiles, J.K., Jolly, C.M. and Aggarwal, D., 2004. Human aflatoxicosis in developing countries: a review of toxicology, exposure, potential health consequences, and interventions. American Journal of Clinical Nutrition 80: 1106-1122.

Wogan, G. and Goldblatt, L., 1969. Aflatoxin - scientific background, control and implications. Aflatoxin. Academic Press, New York, NY, USA, pp. 151-186.

Woo, C. and El-Nezami, H., 2014. Mycotoxins in Asia: is China in danger? Quality Assurance and Safety of Crops and Foods 7: 3-25.

World Health Organization (WHO), 2018. Aflatoxins. Available at: https://www.who.int/foodsafety/FSDigest_Aflatoxins_EN.pdf

Wu, L., Ding, X., Li, P., Du, X., Zhou, H., Bai, Y.Z. and Zhang, L., 2016a. Aflatoxin contamination of peanuts at harvest in China from 2010 to 2013 and its relationship with climatic conditions. Food Control 60: 117-123.

Wu, L., Li, J., Li, Y., Li, T., He, Q., Tang, Y., Liu, H., Su, Y., Yin, Y. and Liao, P., 2016b. Aflatoxin B1, zearalenone and deoxynivalenol in feed ingredients and complete feed from different Province in China. Journal of Animal Science and Biotechnology 7: 63.

Xie, H., Wang, X., Zhang, L., Wang, T., Zhang, W., Jiang, J., Chang, P.-K., Chen, Z.-Y., Bhatnagar, D. and Zhang, Q., 2018. Monitoring metabolite production of aflatoxin biosynthesis by orbitrap fusion mass spectrometry and a D-optimal mixture design method. Analytical Chemistry 90: 14331-14338.

Xie, L., Chen, M. and Ying, Y., 2016. Development of methods for determination of aflatoxins. Critical Reviews in Food Science and Nutrition 56: 2642-2664.

Xiulan, S., Xiaolian, Z., Jian, T., Xiaohong, G., Jun, Z. and Chu, F., 2006. Development of an immunochromatographic assay for detection of aflatoxin $B_{1}$ in foods. Food Control 17: 256-262.

Xu, H.-Z., Sun, G.-J., Wang, S.-K., Chen, G.-W., Sheng, J.-L. and Wang, J.-S., 2006. Determination of aflatoxins and fumonisins in the corn and peanut on sale. Journal of Environmental \& Occupational Medicine 3.

Yang, X., Zhang, Q., Chen, Z.-Y., Liu, H. and Li, P., 2017. Investigation of pseudomonas fluorescens strain 3JW1 on preventing and reducing aflatoxin contaminations in peanuts. PLoS ONE 12: e0178810.

Yin, Y., Lou, T., Yan, L., Michailides, T. and Ma, Z., 2009. Molecular characterization of toxigenic and atoxigenic Aspergillus flavus isolates, collected from peanut fields in China. Journal of Applied Microbiology 107: 1857-1865.

Yin, Y.-N., Yan, L.-Y., Jiang, J.-H. and Ma, Z.-H., 2008. Biological control of aflatoxin contamination of crops. Journal of Zhejiang University Science B 9: 787-792.

Yu, J., 2012. Current understanding on aflatoxin biosynthesis and future perspective in reducing aflatoxin contamination. Toxins 4: 1024-1057.

Yu, J., Cleveland, T.E., Nierman, W.C. and Bennett, J.W., 2005. Aspergillus flavus genomics: gateway to human and animal health, food safety, and crop resistance to diseases. Revista Iberoamericana de Micología 22: 194-202. 
Yu, Q., Zhou, C., Wang, J., Chen, L., Zheng, S. and Zhang, J., 2013. A functional insertion/deletion polymorphism in the promoter of PDCD6IP is associated with the susceptibility of hepatocellular carcinoma in a Chinese population. DNA and Cell Biology 32: 451-457.

Yuan, J., Li, D., Qin, L., Shen, J., Guo, X., Tumukunde, E., Li, M. and Wang, S., 2019. HexA is required for growth, aflatoxin biosynthesis and virulence in Aspergillus flavus. BMC Molecular Biology 20: 4.

Zhang, B., Chen, X., Han, S.-Y., Li, M., Ma, T.-Z., Sheng, W.-J. and Zhu, X., 2018a. Simultaneous analysis of 20 mycotoxins in grapes and wines from Hexi corridor region (China): based on a QuEChERSUHPLC-MS/MS method. Molecules 23: 1926.

Zhang, C., Selvaraj, J., Yang, Q. and Liu, Y., 2017. A survey of aflatoxin-producing Aspergillus sp. from peanut field soils in four agroecological zones of China. Toxins 9: 40.

Zhang, D., Li, P., Yang, Y., Zhang, Q., Zhang, W., Xiao, Z. and Ding, $X ., 2011 a$. A high selective immunochromatographic assay for rapid detection of aflatoxin $\mathrm{B}_{1}$. Talanta 85: 736-742.

Zhang, F., Guo, Z., Zhong, H., Wang, S., Yang, W., Liu, Y. and Wang, S., 2014. RNA-Seq-based transcriptome analysis of aflatoxigenic Aspergillus flavus in response to water activity. Toxins 6: 3187-3207.

Zhang, H., He, J., Li, B., Xiong, H., Xu, W. and Meng, X., 2011b. Aflatoxin contamination and research in China. Aflatoxins detection, measurement and control. IntechOpen, London, UK.

Zhang, L., Dou, X.-W., Zhang, C., Logrieco, A. and Yang, M.-H., 2018b. A review of current methods for analysis of mycotoxins in herbal medicines. Toxins 10: 65 .

Zhang, S., Schwelm, A., Jin, H., Collins, L.J. and Bradshaw, R.E., 2007. A fragmented aflatoxin-like gene cluster in the forest pathogen Dothistroma septosporum. Fungal Genetics and Biology 44: 1342-1354.
Zhang, W., Ye, Z., Jin, Y., Wang, S., Zhang, L. and Pei, X., 2013. Management of mycotoxin contamination in food and feed in China. World Mycotoxin Journal 7: 53-62.

Zhang, X., Liu, H. and Chen, J., 2005. Immunoaffinity column cleanup with liquid chromatography using post-column bromination for aflatoxins in medicinal herbs and plant extracts. Journal of Chromatographic Science 43: 47-51.

Zhang, Z., Tang, X., Wang, D., Zhang, Q., Li, P. and Ding, X., 2015. Rapid on-site sensing aflatoxin $B_{1}$ in food and feed via a chromatographic time-resolved fluoroimmunoassay. PLoS ONE 10: e0123266.

Zhao, X., Schaffner, D.W. and Yue, T., 2013. Quantification of aflatoxin risk associated with Chinese spices: point and probability risk assessments for aflatoxin $B_{1}$. Food Control 33: 366-377.

Zheng, J., Yin, Y. and Li, B., 2010. A new scheme for climate regionalization in China. Acta Geographica Sinica 65: 3-12.

Zheng, P., Xia, Y., Xiao, G., Xiong, C., Hu, X., Zhang, S., Zheng, H., Huang, Y., Zhou, Y. and Wang, S., 2012. Genome sequence of the insect pathogenic fungus Cordyceps militaris, a valued traditional Chinese medicine. Genome Biology 12: R116.

Zheng, R., Xu, H., Wang, W., Zhan, R. and Chen, W., 2014. Simultaneous determination of aflatoxin $B_{1}, B_{2}, G_{1}, G_{2}$, ochratoxin $\mathrm{A}$, and sterigmatocystin in traditional Chinese medicines by LCMS-MS. Analytical and Bioanalytical Chemistry 406: 3031-3039.

Zhu, C.-Y., Ying, Y.-F., Wei, M.-J., Chen, H.-H., Lu, C.-B., Zhou, W.-H., Lin, X.-J. and Luo, C.-J., 2010. Determination of aflatoxins in feeds by liquid chromatography-tandem mass spectrometry. Journal of Chinese Mass Spectrometry Society 2010-4. Available at: https:// tinyurl.com/rwamsuy. 